Published in final edited form as:

Exp Eye Res. 2009 February ; 88(2): 151-164. doi:10.1016/j.exer.2008.08.002.

\title{
The Lens Capsule
}

\author{
Brian P. Danysh and Melinda K. Duncan ${ }^{*}$ \\ Department of Biological Sciences, University of Delaware, Newark, DE 19716 USA
}

\begin{abstract}
The lens capsule is a modified basement membrane that completely surrounds the ocular lens. It is known that this extracellular matrix is important for both the structure and biomechanics of the lens in addition to providing informational cues to maintain lens cell phenotype. This review covers the development and structure of the lens capsule, lens diseases associated with mutations in extracellular matrix genes and the role of the capsule in lens function including those proposed for visual accommodation, selective permeability to infectious agents, and cell signaling.
\end{abstract}

The lens capsule is an uninterrupted basement membrane completely enclosing the lens, sequestering it from the other ocular tissues and protecting it from infectious viruses and bacteria (Beyer et al., 1984; Cotlier et al., 1968; Karkinen-Jaaskelainen et al., 1975). Although its composition is similar to other basement membranes, its physical characteristics and variety of functions set it apart. The lens capsule has evolved into a strong transparent membrane, refractive index of 1.4 (Danysh et al., 2008a), capable of shaping the lens and its surface curvature by participating in the accommodation mechanism in primates (Fincham, 1937; Fisher, 1969b; Fisher and Pettet, 1972; Krag and Andreassen, 1996; Schachar, 2006; Schachar and Koivula, 2008). In addition to its physical and mechanical roles, the lens capsule provides vital epitopes for lens cell surface receptors which enhance lens cell survival (Oharazawa et al., 1999) as well as promoting regional cell migration and differentiation (Blakely et al., 2000; Tholozan et al., 2007; Wormstone et al., 1997). Besides the epitopes contained in its structural molecules, the lens capsule provides a reservoir of sequestered growth factors that, after their release and activation, promote differentiation of the lens cells (Robinson, 2006; Tholozan et al., 2007). As the lens is avascular, the capsule must also allow for the passive exchange of metabolic substrates and waste in an out of the lens (Fisher, 1977; Friedenwald, 1930a), while selectively filtering intermediate sized molecules based on size and charge (Danysh et al., 2008b; Friedenwald, 1930b; Lee et al., 2006). Finally, the thickness and long term stability of the lens capsule in the eye makes extracapsular cataract surgery with implantation of intraocular lenses possible (Guthoff et al., 1990; Thim et al., 1991). Here we review many aspects of lens capsule structure and function.

\section{Lens Capsule Development}

The eye begins to form as a result of mutually inductive interactions between the head ectoderm and the neuroepithelium of the optic vesicle shortly after neurulation (around 8.5 days post coitum (dpc) in mice) (Lang, 2004; Pei and Rhodin, 1970). A basement membrane is first detected at the basal surface of the head ectoderm resulting in its separation from the underlying

\footnotetext{
*To whom all the correspondence should be addressed: Melinda K. DuncanDepartment of Biological Sciences University of DelawareNewark, DE 19716 Telephone: (302) 831-0533 Fax: (302) 831-2281 E-mail address: E-mail: duncanm@udel.edu.

Publisher's Disclaimer: This is a PDF file of an unedited manuscript that has been accepted for publication. As a service to our customers we are providing this early version of the manuscript. The manuscript will undergo copyediting, typesetting, and review of the resulting proof before it is published in its final citable form. Please note that during the production process errors may be discovered which could affect the content, and all legal disclaimers that apply to the journal pertain.
} 
mesenchyme around this time (Center and Polizotto, 1992; Csato, 1989; Peterson et al., 1995). The head ectoderm overlying the optic vesicle begins to thicken by mouse $9.5 \mathrm{dpc}$ forming the lens placode. In humans and rats, but not in chicks, cytoplasmic processes associated with network forming fibrils have been observed extending between these two tissues at this stage (Hunt, 1961; McAvoy, 1981). These processes are coated with an amorphous material that may be associated with the basement membrane (Hunt, 1961; McAvoy, 1981). The lens placode then invaginates, forming the lens pit by mouse $10.5 \mathrm{dpc}$ (Lovicu and McAvoy, 2005; Lovicu and Robinson, 2004). At this point, the basement membrane underlying the lens pit is approximately $40 \mathrm{~nm}$ thick in the mouse (Csato, 1989). As the lens pit deepens, the cytoplasmic processes begin to disappear (McAvoy, 1981), while the basement membrane of the lens pit continues to thicken due to matrix molecule secretion by the pit cells (Csato, 1989). The pit pinches off from the surface ectoderm as the cells of the pit delaminate from the head ectoderm and develop cell-cell contacts with the opposite pit edge forming the lens vesicle (mouse E11.5) (Lovicu and McAvoy, 2005; Lovicu and Robinson, 2004). This process also requires fusion of the edges of the basement membrane underlying the pit leading to a lens vesicle that is completely surrounded by the basement membrane, now properly called the lens capsule (Lovicu and McAvoy, 2005; Lovicu and Robinson, 2004; Parmigiani and McAvoy, 1984). This seals the developing lens off from direct contact with the surrounding ocular environment creating an immune privileged lens (Coulombre, 1979) protected from bacterial and viral invasion (Beyer et al., 1984; Cotlier et al., 1968; KarkinenJaaskelainen et al., 1975). However, the permeability of the lens capsule to water, small solutes and many proteins allows lens growth and metabolism to proceed (Fisher, 1977; Friedenwald, 1930a; Friedenwald, 1930b; Sabah et al., 2005; Sabah et al., 2004).

The cells in the posterior portion of the lens vesicle leave the cell cycle and elongate into the primary lens fibers while the anterior surface of the lens vesicle begins to proliferate rapidly which forms a pool of lens epithelial cells as well as the creation of the precursors to the adult lens fiber cells. Elongation and organelle degradation of these lens fiber cell precursors (see Bassnett review in this issue) results in the formation of lens fibers which comprise the bulk of the adult lens (Cvekl and Duncan, 2007; Cvekl and Tamm, 2004). In the embryo, both lens epithelial and fiber cells synthesize and secrete basement membrane molecules facilitating the growth of the anterior, posterior, and equatorial lens capsule. Pulse labeling studies have demonstrated that the embryonic capsule consists of successive layers of lamellae which first form adjacent to lens cells, then are buried within the capsule as new layers of basement membrane are laid down around the rapidly growing embryonic lens (Haddad and Bennett, 1988; Parmigiani and McAvoy, 1984; Parmigiani and McAvoy, 1991; Young and Ocumpaugh, 1966). By $15.5 \mathrm{dpc}$ in the mouse, the posterior capsule has thickened to approximately $350 \mathrm{~nm}$ and distinct lamellae are observable by transmission electron microscopy (Csato, 1989). At this stage in mice and rats, the posterior capsule appears thicker than the anterior; however it is difficult to clearly discriminate between the lens basement membrane and the basement membrane of the tunica vasculosa (see Beebe article in this issue) at this age (Kelley et al., 2002; Parmigiani and McAvoy, 1989). By mouse $17.5 \mathrm{dpc}$, the lamellae begin to become less apparent morphologically and by mouse $19.5 \mathrm{dpc}$ (around birth), the capsule has an almost uniform thickness (Fisher and Pettet, 1972) of over $500 \mathrm{~nm}$ and its ultrastructure has become more homogeneous (Csato, 1989).

The mechanisms controlling capsular synthesis and the specification of the basal surface of lens cells are unclear. During lens reconstitution from epithelium/capsule fragments in the developing chick, cells that lose contact with the basement membrane undergo anoikis (apoptosis due to loss of matrix attachment) while cells attached to the capsule fragment migrate to reestablish their normal polarity within the eye. After the basal ends of the cells are reoriented, they reform a capsule on the surface facing away from the newly formed lens vesicle (Coulombre and Coulombre, 1971). This strongly suggests that the lens capsule is critical for 
lens cell survival and the gradient of factors secreted by the anterior and posterior eye tissues specify the orientation of the lens cells and signal for the formation of the lens capsule. The synthesis of the lens capsule also appears to be critical for lens morphogenesis since the first detectable abnormality in the anophthalmia (Webster and Zwaan, 1984), mylencephalic bleb (Center and Polizotto, 1992), and trisomy one (Smith, 1989) mouse mutants is the delayed or absent synthesis of ECM molecules.

Postnatally, both the lens epithelium and fiber cells continue to deposit matrix molecules to the inner surface of the thickening capsule (Haddad and Bennett, 1988; Young and Ocumpaugh, 1966). Additionally, metabolic pulse labeling and copper reabsorption following lenticular chalcosis studies of the capsule have demonstrated that its matrix turns over extremely slowly, with a turnover rate measuring in months and years (Haddad and Bennett, 1988; Seland, 1976; Young and Ocumpaugh, 1966) compared to the hours measured for other basement membranes (Beavan et al., 1989; Dunsmore et al., 1995; Young and Ocumpaugh, 1966). In the human eye, the lens capsule remains intact for decades following removal of lens cells during extracapsular cataract extraction, allowing for the insertion and stability of artificial intraocular lenses (IOLs) and the emerging designs of accommodating IOLs (Bruck, 1993). The very slow turnover rate of capsular components (Fisher and Pettet, 1972; Seland, 1976; Young and Ocumpaugh, 1966) in concert with the continued deposition of capsular matrix results in a relatively thick membrane with regional thickness differences that continues to grow throughout life (Barraquer et al., 2006; Fincham, 1937; Fisher and Pettet, 1972; Krag et al., 1997; Parmigiani and McAvoy, 1989; Young and Ocumpaugh, 1966).

Depending on species, the lens increases 20-200 fold in surface area from its initial formation until adulthood (Coulombre, 1979). Since the lens substance is completely enclosed by the lens capsule and new capsular material is added only to the inner surface of the capsule after its secretion by lens cells (Johnson and Beebe, 1984; Rafferty and Goossens, 1978), some unknown mechanism must allow the capsule to increase in surface area as the lens grows (Coulombre, 1979). In other tissues, synthesis and degradation of the basement membrane is dynamically controlled in response to functional pressure. For instance, it has been estimated that over $10 \%$ of the alveolar basement membrane is degraded and resynthesized each day (Dunsmore et al., 1995; Dunsmore and Rannels, 1995; Dunsmore and Rannels, 1996).

However, this seems unlikely to be the major mechanism allowing for expansion of lens capsule area since the core proteins of the lens capsule do not significantly turnover throughout life (Johnson and Beebe, 1984; Rafferty and Goossens, 1978; Sundelin and Sjostrand, 1999; Young and Ocumpaugh, 1966). Overall the molecular mechanisms leading to the expansion of lens capsule area during development are not known. Notably though, a number of laboratories have observed that the lens capsule does change its physical, biomechanical, and biochemical properties with aging (Fisher, 1969a; Friedenwald, 1930a; Fukushi and Spiro, 1969; Krag and Andreassen, 2003b; Krag et al., 1997; Parmigiani and McAvoy, 1991; Seland, 1974) which may be the result of the mechanisms allowing the lens capsule area to keep pace with lens growth.

The adult lens is suspended between the anterior and posterior chambers of the eye by zonules which originate from and are produced by the ciliary processes (Hanssen et al., 2001) (Figure 1). Anterior, equatorial, and posterior zonules integrate into the lens capsule near the equator (Canals et al., 1996; Mir et al., 1998) of the lens and are used to transmit accommodative forces from the ciliary processes to the lens in primates. In these regions, bundles of zonules spread into smaller fibrillar networks that seem to blend into the capsule matrix (Hansson, 1970; Streeten, 1977). However, the mechanisms by which this insertion occurs and the regulation necessary to form reproducible zonular organizations is not yet known. 


\section{Lens Capsule Molecular Composition and Interactions}

The slow turnover rate and steady deposition of matrix material by lens cells makes the lens capsule an extremely thick membrane (Barraquer et al., 2006; Fisher and Pettet, 1972; Krag et al., 1997; Young and Ocumpaugh, 1966). Surprisingly though, its molecular composition is quite similar to other, thinner basement membranes. Adult lens capsules are composed of interacting networks of laminin (Cammarata et al., 1986; Kohno et al., 1987; Muraoka and Hayashi, 1993; Parmigiani and McAvoy, 1984) and type IV collagen (Brinker et al., 1985; Cammarata et al., 1986; Kelley et al., 2002) in addition to entactin/nidogen (Cammarata et al., 1986; Dong et al., 2002), and several heparan sulfate proteoglycans; predominately perlecan (Cammarata et al., 1986; Laurent et al., 1978; Peterson et al., 1995; Rossi et al., 2003) and collagen XVIII (Fukai et al., 2002) while possibly also containing collagen XV (Ylikarppa et al., 2003b) and agrin (Fuerst et al., 2007; http://neibank.nei.nih.gov, 2008). These molecules have consistently been found in most basement membranes in a variety of species and tissues. The core structural molecules, laminin, collagen IV, nidogen, and perlecan, self-assemble into a three dimensional matrix (Figure 2) that provides structural, protective, and signaling roles to the developing and mature lens. Additionally, fibrillin fibers have been found in the capsule, however only in the equatorial regions overlapping and adjacent to zonule insertion (Figure 1). The most intense staining for fibrillin is found in a morphologically distinct outer layer called the zonular lamella (Mir et al., 1998; Streeten, 1977; Wheatley et al., 1995) which consists of interlaced zonules and capsule matrix. Marfan syndrome patients have a mutation in the fibrillin-1 gene and are prone to dislocated lenses in addition to severe myopia, glaucoma, and cataract formation (Ammash et al., 2008). Elastic fiber components of the zonules are also likely interdigitated into the lens capsule (Garner and Alexander, 1986) and may be important for capsule stability in the region of zonule insertion. Notably, it was recently shown that certain polymorphisms in the lysyl oxidase-like 1 (LOXL1) gene, an enzyme required for elastic fiber formation, are a major risk factor for pseudoexfoliation syndrome (Aragon-Martin et al., 2008; Mossbock et al., 2008; Thorleifsson et al., 2007), a condition associated with lens subluxation, lens capsule weakness, and glaucoma (Naumann et al., 1998).

Interactions between all of the molecules found in the lens capsule and their temporal and spatial incorporation have been shown to be quite complex.

\section{Laminin}

Laminins are glycoproteins consisting of three subunits, $\alpha, \beta$, and $\gamma$ which play a vital role in the formation of all basement membranes. There are five known $\alpha$, four known $\beta$, and three known $\gamma$ subunits, which can combine intracellularly into fifteen different cross-shaped heterotrimeric isoforms (Hallmann et al., 2005). Extracellularly, the heterotrimers associate with cell membrane bound dystroglycans and integrins through their long arms and then polymerize via their short arms into regular polygonal sheets creating initial scaffolding for the other basement membrane molecules to adhere (Aumailley and Smyth, 1998; Cheng et al., 1997; Colognato and Yurchenco, 2000; Henry and Campbell, 1998; Kefalides and Borel, 2005) (Figure 2).

The fifteen different laminin isoforms are tissue specific (Li et al., 2002).

Immunohistochemical studies have shown reactivity for five laminin subunits, lam- $\alpha 1$, lam$\alpha 5$, lam- $\beta 1$, lam- $\beta 2$, and lam- $\gamma 1$, at all stages of lens capsule development in humans (Bystrom et al., 2006; Kohno et al., 1987), and embryonic and adult bovines (Cammarata et al., 1986), rats (Parmigiani and McAvoy, 1984; Parmigiani and McAvoy, 1991), mice (Belford et al., 1987), and zebrafish (Lee and Gross, 2007; Semina et al., 2006; Zinkevich et al., 2006).

In embryonic zebrafish, knockdown or missense mutations in lam- $\alpha 1$ result in lens degeneration (Zinkevich et al., 2006) and membrane blebbing during lens vesicle formation 
(Semina et al., 2006), respectively. In addition, embryonic zebrafish with insertional mutations in lam- $\beta 1$ and lam- $\gamma 1$ had dysplastic lenses which were un-attached to the anterior chamber (Lee and Gross, 2007). Humans with mutations in lam- $\beta 2$ have phenotypes associated with Pierson Syndrome with several eye development abnormalities including abnormal lens shape, posterior lenticonus and cataract (Zenker et al., 2004), however, no lens phenotype is described in mice with a knockout for lam- $\beta 2$ (Noakes et al., 1995).

\section{Collagen IV}

Another molecule ubiquitous to basement membrane matrices including the lens capsule (Brinker et al., 1985; Cammarata et al., 1986) is collagen IV, which forms an integrated network within the laminin scaffold providing the strength and stability required by many basement membranes. Collagen IV is encoded by six different genes, col4 $\alpha 1$ through col4a6. Each monomer contains a C-terminal non-collagenous domain ( $\mathrm{NC1}$ ), a long triple helical domain containing glycine repeats with frequent interruptions, and an N-terminal 7S domain. The isoforms first self-assemble within the endoplasmic reticulum into one of three heterotrimers, $\alpha 1 \alpha 1 \alpha 2, \alpha 3 \alpha 4 \alpha 5$, or $\alpha 5 \alpha 5 \alpha 6$ which are also called collagen IV protomers. Upon secretion, multiple triple helical collagen IV protomers can super-helically twist around each other forming extensive lateral associations. Furthermore, the $\mathrm{NC} 1$ domains of two non-laterally associated protomers dimerize, while each protomer's $7 \mathrm{~S}$ domain tetramerizes with three other collagen IV protomers creating an irregular polygonal meshwork capable of forming lateral associations with other basement membrane molecules (Figure 2) (Charonis et al., 1986; Chen and Hansma, 2000; Kuhn, 1995; Laurie et al., 1986; Yurchenco and Ruben, 1987; Yurchenco et al., 1986). Consistent with the super-helical twisting, recent modeling has proposed a topology for the collagen IV meshwork as predominately containing three-way junctions and irregular hexagonal fenestrations (Burd, 2008).

Three different collagen IV networks are known to form and all have been found in the lens capsule, $\alpha 1 \alpha 1 \alpha 2: \alpha 1 \alpha 1 \alpha 2, \alpha 3 \alpha 4 \alpha 5: \alpha 3 \alpha 4 \alpha 5$, or $\alpha 1 \alpha 1 \alpha 2: \alpha 5 \alpha 5 \alpha 6$ (Gay and Miller, 1979; Kelley et al., 2002; Kleppel and Michael, 1990; Kleppel et al., 1989). The $\alpha 1 \alpha 1 \alpha 2: \alpha 1 \alpha 1 \alpha 2$ and $\alpha 1 \alpha 1 \alpha 2: \alpha 5 \alpha 5 \alpha 6$ networks play a significant role in tissue development and function. Embryonic mice without functional col $4 \alpha 1$ and col $4 \alpha 2$ alleles die by day E9.5 with noticeable basement membrane discontinuities and ruptures in many tissues (Poschl et al., 2004). However, mice heterozygous for a point mutation affecting the glycine repeats within the triple helical domain of col4 $\alpha 1$ display several abnormalities in the anterior eye segment (Gould et al., 2007) including irregular lens capsules with local interruptions and vacuolar cataracts (Van Agtmael et al., 2005).

The only two collagen IV networks present in embryonic human and mouse lens capsules from early lens pit formation until just after birth are $\alpha 1 \alpha 1 \alpha 2: \alpha 1 \alpha 1 \alpha 2$ and $\alpha 1 \alpha 1 \alpha 2: \alpha 5 \alpha 5 \alpha 6$ (Kelley et al., 2002). These two collagen IV networks have fewer disulfide cross-links than the $\alpha 3 \alpha 4 \alpha 5: \alpha 3 \alpha 4 \alpha 5$ network, which begins to be incorporated into the lens capsule shortly after birth in mice (Kelley et al., 2002). It is possible that the need for the fast growing embryonic lens to expand followed by the requirement of a stronger capsule postnatally capable of maintaining normal lens shape and structural stability might explain the late addition of the $\alpha 3 \alpha 4 \alpha 5: \alpha 3 \alpha 4 \alpha 5$ network. The integration of the stronger $\alpha 3 \alpha 4 \alpha 5: \alpha 3 \alpha 4 \alpha 5$ network also seems vital for the capsule to endure the forces applied by the ciliary apparatus and zonules. Humans lacking one of the subunits to form this network have phenotypes associated with Alport's Syndrome, which include proteinuria, deafness, and several lens defects. The vast majority of these patients have the X-linked version of Alport's and lack a functional collagen IV $\alpha 5$ allele. These patients have thinner, more fragile capsules resulting in anterior and posterior lenticonus, capsular ruptures, and cataract (Colville and Savige, 1997; Olitsky et al., 1999; Takei et al., 2001; Wilson et al., 2006). Patients with the autosomal recessive version, lacking functional 
col $4 \alpha 3$ or col $4 \alpha 4$ alleles, can also have similar capsule phenotypes as the X-linked version (Colville et al., 1997). Conversely, collagen IV $\alpha 3$ null mice (Cosgrove et al., 1996; Miner and Sanes, 1996) lack any lens phenotypes (Danysh and Duncan, unpublished data) perhaps because they die by 8 weeks of age. Since it is believed that nocturnal rodents do not accommodate and hence do not experience the accompanying capsular stresses (Sivak, 1980), mouse lenses might not be as sensitive to the loss of the $\alpha 3 \alpha 4 \alpha 5: \alpha 3 \alpha 4 \alpha 5$ network as human lenses. Interestingly, humans with autosomal dominant Alport's typically harboring point mutations in either the collagen $\alpha 3$ (IV) or $\alpha 4$ (IV) genes have not been reported to have any lens abnormalities (Colville et al., 2000; Jefferson et al., 1997).

\section{Nidogen/Entactin}

Collagen IV and laminin form the two main networks of ECM molecules found in basement membranes including the lens capsule. Two additional molecules, nidogen and a class of molecules called heparan sulfate proteoglycans stabilize these two independent networks into a single three dimensional matrix (Fox et al., 1991) (Figure 2). Nidogen, which is also known as entactin, is a single chain sulfated glycoprotein ubiquitous to all basement membranes (Timpl and Brown, 1996). It is encoded by two different genes, nidogen-1 and nidogen-2, which share $46 \%$ sequence identity (Kohfeldt et al., 1998). Both nidogen isoforms can bind to laminin and collagen IV, in addition to perlecan's core protein (Farach-Carson and Carson, 2007; Kohfeldt et al., 1998). Further, these isoforms are generally capable of compensating for each other, as has been shown for most tissues of nidogen-1 or nidogen-2 single mutant mice (Bader et al., 2005; Gersdorff et al., 2007; Murshed et al., 2000; Schymeinsky et al., 2002). Most reports on nidogen null mice do not note lens capsule defects (Bader et al., 2005; Bose et al., 2006; Gersdorff et al., 2007; Lebel et al., 2003; Murshed et al., 2000), however one investigator describes an irregular fiber cell/posterior capsule boundary containing fiber cells protruding into the capsule presumably arising from the lack of nidogen-2 expression in the lens (Dong et al., 2002). Interestingly, the glomerular basement membranes of nidogen-1 null mice show molecular organizational and functional differences. The glomerular basement membranes of these mice possess alterations in the distribution of anionically charged sites and in the permeability to endogenous albumin (Lebel et al., 2003), which has yet to be investigated in their lens capsules.

\section{Heparan Sulfate Proteoglycans}

Heparan sulfate proteoglycans (HSPG) are another class of molecules which are part of the core ultrastructure of basement membranes. HSPGs have several attached sulfated glycosaminoglycan (GAG) side chains which initiate at specific consensus Ser-Gly residues on the core protein (Perrimon and Bernfield, 2000) and can be several hundred nanometers in length (Iozzo, 2001). These side chains are anionic, and along with the carboxyl groups from acidic amino acid residues, result in the capsule having a net anionic charge (Friedenwald, 1930b; Winkler et al., 2001). These anionic sites are unevenly distributed within the capsule and appear most abundant along the outer and inner surfaces in young human (Winkler et al., 2001), mouse (Webster et al., 1987), and rabbit (Landemore et al., 1999) capsules. This appears to alter during aging in humans since older human lens capsules appear to have a more even distribution of anionic sites compared to younger lens capsules (Winkler et al., 2001).

There are two major HSPGs that have been confirmed to be present in the lens capsule; perlecan and collagen XVIII (Fukai et al., 2002; Rossi et al., 2003; Ylikarppa et al., 2003b). Additionally, agrin has been detected in the capsules of embryonic mouse lenses in one report (Fuerst et al., 2007) and agrin mRNA was found in the NEI bank adult human lens expressed sequence tag database. Despite this, agrin protein has not been reported in adult human lens capsules nor are there any lens capsule defects described in agrin null mice (Gautam et al., 1999; Hausser et al., 2007). Similarly, collagen XV has been found in the lens capsules of sixteen day old 
mice, but null mice have no noticeable lens capsule defects although they exhibit abnormal tunica vasculosa regression (Ylikarppa et al., 2003b).

HSPGs have varying binding affinities toward each other as well as the basement membrane molecules, laminin, collagen IV, nidogen, and fibronectin (Iozzo, 2005; Kramer, 2005; Timpl and Brown, 1996). The highly sulfated GAG side chains can also bind growth factors (Lamanna et al., 2007; Uchimura et al., 2006) and serve as reservoirs, possibly protecting the factors from proteases. The side chains have been known to associate with growth factors such as fibroblast growth factor-2 (FGF2), hepatocyte growth factor (HGF), and platelet derived growth factor (PDGF) (Chu et al., 2005; Kreuger et al., 2005), molecules which are essential for lens growth and development (Lovicu and McAvoy, 2005).

\section{Perlecan}

Perlecan is common to almost all basement membranes (Handler et al., 1997). It is incorporated into the main scaffolding of the lens capsule through both its core protein and three to four GAG side chains. The core protein domains are capable of binding integrin receptors as well as forming dimers, and binding nidogen and laminin-nidogen complexes. Perlecan has also been reported to potentially interact with collagen XVIII and endostatin, collagen XVIII's cleaved NC1 domain (Marneros et al., 2004; Marneros and Olsen, 2005; Miosge et al., 2003; Mongiat et al., 2003). The GAG side chains readily bind the main capsule matrix structural molecules laminin, collagen IV and nidogen (Figure 2), in addition to fibronectin (Battaglia et al., 1992; Farach-Carson et al., 2008; Farach-Carson and Carson, 2007; Hopf et al., 1999; Iozzo, 2005; Kramer, 2005; Timpl and Brown, 1996). The presence of perlecan GAG side chains appears to be critical for the normal structure of the lens capsule, but not other basement membranes. Mice lacking three of the GAG attachment sites in the core perlecan protein are normal with the exception of equatorial and posterior capsule leaks in newborns, which develop into capsular degeneration and ruptures by three weeks of age (Rossi et al., 2003). The capsule degeneration is accelerated when these perlecan mutant mice are mated with mice containing knockouts of collagen XVIII (Rossi et al., 2003). It is possible that perlecan is the major HPSG in the lens capsule but plays a smaller role in other basement membranes which allows other HPSGs such as agrin and collagen XVIII to compensate for its loss.

\section{Collagen XVIII}

Collagen XVIII is also widely distributed in mammalian basement membranes and found in the lens capsules of newborn and 16 day old mice (Fukai et al., 2002; Ylikarppa et al., 2003a; Ylikarppa et al., 2003b). Humans lacking collagen XVIII are diagnosed with Knobloch syndrome and have variable expression of ocular phenotypes. Most are highly myopic with various degrees of cataract and lens subluxation (Iozzo, 2005). Collagen XVIII has been reported to bind to the basement membrane scaffolding molecules, laminin, nidogen, and perlecan, through its $\mathrm{NC} 1$ domain but no structural or signaling role in the mouse lens capsule has been shown (Fukai et al., 2002; Kramer, 2005; Marneros and Olsen, 2005). However, the irises of collagen XVIII null mice have enhanced adhesion to the lens capsule (Ylikarppa et al., 2003a) while its cleaved C-terminal NC1 domain (endostatin) has been shown to be an anti-angiogenic factor (Sasaki et al., 1998). Although endostatin is involved in regression of hyaloid vessels along the inner limiting membrane of the retina, it has not been shown to be involved in tunica vasculosa regression (Fukai et al., 2002).

\section{Fibronectin}

Fibronectin is a homodimeric glycoprotein commonly found in serum (Johansson et al., 1997) but is also present as a minor component of some basement membranes (Cammarata et al., 1986; Laurie et al., 1983). It is capable of binding both HPSGs and collagen IV in the capsule (Dessau et al., 1978; Ruoslahti et al., 1981; Ruoslahti et al., 1982) as well as several 
integrin receptors in the lens cell membranes (Johansson et al., 1997). Fibronectin has been detected in the lens capsule of embryonic chicks during lens placode formation (Kurkinen et al., 1979) and in rats during lens vesicle formation, however it has not been detected in rat embryonic day nineteen lens capsules (Parmigiani and McAvoy, 1984; Parmigiani and McAvoy, 1991). Its presence in adult lens capsules is debatable. Fibronectin has been detected throughout the adult mouse posterior capsule (Duncan et al., 2000) but only on the outer surfaces of the anterior and equatorial capsules of adult rats (Sramek et al., 1987), mice (Duncan et al., 2000), and humans (Kohno et al., 1987) or not at all in purified extracts of calf anterior capsules (Brinker et al., 1985). If fibronectin is a component of the capsule, its source is not known as it is not produced or secreted by either cultured bovine epithelial explants or epithelial cells from cultured rabbit lenses (Lee and Joo, 1999); although fibronectin was detected in the fiber cells of transgenic mice over expressing Pax6(5a) in the lens (Duncan et al., 2000). Human fibronectin intravenously introduced into mice co-localized with and was indistinguishable from the endogenous protein (Oh et al., 1981) hence its presence in the capsule may be from soluble fibronectin via the vitreous and aqueous humors.

It is possible that fibronectin serves more as a cell signaling molecule rather than as a structural component of basement membranes. It has been proposed that fibronectin may play a role in lens wound healing and posterior capsule opacification (PCO) as it is released from lens epithelial cells undergoing EMT (Lee and Joo, 1999) and promotes epithelial cell attachment and migration of lens epithelial cell explants from young embryonic rats (Parmigiani and McAvoy, 1991), adult human (Oharazawa et al., 1999) and rabbit lenses (Olivero and Furcht, 1993).

\section{SPARC}

SPARC (also called osteonectin) is a monomeric glycoprotein that has been associated with the lens capsule, and like fibronectin, is considered to serve more in a regulatory role between lens cell and capsule interactions as opposed to involvement in capsular structure. SPARC can bind the growth factors, PDGF, VEGF, and FGF-2 (Brekken and Sage, 2000), and even though it can also bind collagen IV (Mayer et al., 1991), it has not been detected as an integral part of the lens capsule matrices of mice (Yan et al., 2003), humans (Yan et al., 2000), or bovines (Yan and Sage, 1999) but has been found in mouse lens epithelial cells and newly differentiating fiber cells adjacent to the capsule (Yan et al., 2003). Interestingly, adult SPARCdeficient mice develop cataracts and posterior capsule ruptures (Gilmour et al., 1998; Yan et al., 2002) however these phenotypes are most likely due to a role in cell morphology as has been observed in endothelial cells (Goldblum et al., 1994). The posterior lens fiber and anterior epithelial cells in these mice take on an abnormal morphology with protrusions into the capsule creating crevasses (Yan et al., 2002) which are believed to weaken and increase permeability of the capsule to macromolecules (Yan et al., 2002). These mice also have an increase in laminin-1 $(\alpha 1 \beta 1 \gamma 1)$ deposition in the lens capsule, inferring a possible role in basement membrane matrix composition (Yan et al., 2005).

\section{Lens Capsule Biology}

The lens capsule is more than just structural support for the lens within the eye. It also provides the anchor point for the basal surfaces of epithelial and fiber cells, which provides necessary signals for proper lens cell proliferation, migration and differentiation (Bassnett et al., 1999; Blakely et al., 2000; Lu et al., 2008; Oharazawa et al., 1999). Lens cells contain membrane bound integrins capable of binding collagen IV, laminin, fibronectin, and perlecan within the lens capsule through the RGD (Arg-Gly-Asp) amino acid sequence and various other epitopes (Figure 3) (see Menko review in this issue) (Menko et al., 1998; Pedchenko et al., 2004). These cell-capsule interactions have been shown to be required for normal lens development and growth. Notably, $\beta 1$-integrin is required to maintain the lens epithelial cell phenotype in vivo 
(Simirskii et al., 2007) and $\alpha 6$-integrin/ $\alpha 3$-integrin double null mice also have lens epithelial defects (De Arcangelis et al., 1999). $\alpha 6$-integrin is also essential for lens fiber cell

differentiation in vitro (Walker et al., 2002). Human lens epithelial (HLE) cell lines grown on lens capsular bag explants in serum free media readily proliferate and migrate (Wormstone et al., 1997). Similar results with HLE cells grown on tissue culture plates coated with matrix molecules found in the capsule show enhanced survival, attachment, and migration, but not proliferation over those grown just on plastic (Oharazawa et al., 1999). In contrast, primary lens epithelial cells suspended in collagen type I gels rapidly undergo irreversible epithelial to mesenchymal transitions (Greenburg and Hay, 1982; Zuk et al., 1989) similar to those seen in anterior subcapsular cataract (see West-Mays article in this issue) and posterior capsule opacification (see Wormstone review in this issue) (de Iongh et al., 2005). Further, primary HLE cells must be plated on ECM coated dishes to survive and proliferate at rates similar to immortalized HLE cells grown on plastic (Blakely et al., 2000).

The capsule is also considered to be a reservoir for growth factors (Mott and Werb, 2004; Vlodavsky et al., 1991) that have been found to contribute to lens development. Under low serum conditions $(0.1 \%$ FCS $)$, both primary HLEs and HLE cell lines require plating on lens capsule explants or within lens capsular bags for growth (Tholozan et al., 2007; Wormstone et al., 1997). Significant evidence suggests that growth factors are sequestered within the capsule via binding to the heparan sulfate side chains of perlecan and collagen XVIII (Lamanna et al., 2007; Uchimura et al., 2006; Vlodavsky et al., 1991). For instance, several fibroblast growth factors (FGF) have been found bound to the lens capsule. FGF1 and FGF2 have both been found within the anterior, equatorial, and posterior capsule of adult rats in distinct laminae. FGF1 is found along the outer region of the anterior capsule, in a middle band within the equatorial region, and in a band along the inner layer of the posterior capsule (Lovicu and McAvoy, 1993). Conversely, FGF2 is found at higher levels and in multiple bands throughout all regions (Lovicu and McAvoy, 1993). In lens cell explants, recombinant FGF1 and FGF2 are known to promote proliferation and differentiation (Chamberlain and McAvoy, 1987; McAvoy and Chamberlain, 1989) but lens defects have not been described in either FGF1 or FGF2 knockout mice (Dono et al., 1998; Miller et al., 2000) questioning their role in lens development. However, more recently it has been reported that mice with lens cell specific knockouts for two of the four FGF receptors present in lens cells, FGFr1 and FGFr2, develop cataract and microphthalmia. Additionally, mice lacking three of the four receptors, FGFr1, FGFr2, and FGFr3, have very profound lens developmental defects including a lack of cell fiber differentiation, increased cell apoptosis, and a decrease in the synthesis of cell cycle regulators, transcription factors, and crystallins (Zhao et al., 2008). Additionally, studies using FGF19 knockdown zebrafish have shown defects in epithelial cell survival and differentiation into fiber cells but not proliferation (Nakayama et al., 2008). Interestingly, in embryonic chick lenses, FGF19 is found only in the equatorial region (Francisco-Morcillo et al., 2005; Kurose et al., 2005), precisely where a growth factor involved in fiber cell differentiation would be required. However, FGF19 is not found in the chick lens beyond approximately HH stage 26 (Francisco-Morcillo et al., 2005; Kurose et al., 2004; Kurose et al., 2005).

Growth factors sequestered in the lens capsule must be released prior to binding to their respective cell membrane receptors. Matrix metalloproteinases (MMPs), which have endopeptidase activity, along with tissue inhibitors of metalloproteinases (TIMPs) together regulate the release of growth factors from basement membranes and participate in basement membrane remodeling (Tholozan et al., 2007; Vu and Werb, 2000). There are at least twenty three MMPs that have been identified in humans and can be classified into several categories based on their substrate specificity, collagenases, gelatinases, stromelysins, matrilysins, and a membrane-type containing a transmembrane domain (Parks and Shapiro, 2001; Vu and Werb, 2000). All of the secreted MMPs are normally found at low levels in the lens, however two, MMP-2 and MMP-9, are upregulated in lens cells stressed by either cataract surgery, primary 
lens cell culture (Hodgkinson et al., 2007; Wormstone et al., 2002), or cataract (Tamiya et al., 2000). Conversely, the membrane-type MMPs are expressed at relatively high levels in both normal and stressed lenses (Hodgkinson et al., 2007). Upregulation of active MMP-2 and MMP-9 secretion by primary HLE cells cultured on lens capsules frees capsule-bound FGF-2, TGF $\beta$, and VEGF and improves cell survival (Tholozan et al., 2007).

\section{Physical and Biomechanical Properties}

The accessibility of the lens capsule makes it ideal for studying its physical and biomechanical properties. Capsule thickness and material properties are used to develop better cataract surgical techniques (Krag et al., 1993; Thim et al., 1991; Thim et al., 1993) and contributes to a better understanding of how the capsule participates in accommodation and its role in the onset of presbyopia (Fincham, 1937; Schachar, 2006; Schachar and Koivula, 2008; Ziebarth et al., 2008). Studies of the selective diffusion of intermediate sized macromolecules through the lens capsule have been performed to determine its usefulness in tissue replacement and its involvement in the development of cataract. Here we shall discuss the most recent understanding of each.

\section{Capsule Thickness}

Lens capsule thickness is an important consideration in calculating the effects of disease and age on several biomechanical properties (Fisher, 1969a; Krag and Andreassen, 2003b; Krag et al., 1997). The strain energy within the capsule is directly correlated with its thickness (Fisher, 1969a; Fisher, 1969b; Krag and Andreassen, 2003a). This thickness varies with age, along different regions of the capsule, between species (Danysh et al., 2008a; Fincham, 1937; Fisher and Pettet, 1972; Krag et al., 1997; Salzmann, 1912), and different mouse strains (Danysh et al., 2008a). In the accommodative human lens, the capsule is thickest just anterior and posterior to the lens equator, coinciding with the two regions central to zonule insertion, with a thinning of the capsule towards the anterior and posterior poles and central equatorial region (Barraquer et al., 2006; Fincham, 1937; Salzmann, 1912). In contrast, the anterior capsule of non-accommodative lenses are more uniform in thickness although it is thinner towards the equator leading to a dramatic thinning at the posterior pole (Figure 1). The equatorial region and the anterior pole in both accommodative and non-accommodative lenses are approximately five to ten times thicker than the posterior capsular pole (Barraquer et al., 2006; Fisher and Pettet, 1972; Krag and Andreassen, 2003b). For instance, the adult human capsule measures between $25 \mu \mathrm{m}$ and $30 \mu \mathrm{m}$ at the anterior pole, while the anterior poles of the mouse, rat, rabbit, and bovine measure approximately $10 \mu \mathrm{m}, 13 \mu \mathrm{m}, 14 \mu \mathrm{m}$, and $48 \mu \mathrm{m}$ respectively (Danysh et al., 2008a). This is compared to posterior pole measurements between $2 \mu \mathrm{m}$ and $4 \mu \mathrm{m}$ for both human and mouse (Barraquer et al., 2006; Danysh et al., 2008a). In comparison, human capillary basement membranes are approximately $0.1 \mu \mathrm{m}$ thick (Siperstein et al., 1968) while the glomerular basement membrane is approximately $0.3 \mu \mathrm{m}$ thick (Ramage et al., 2002).

\section{Diffusion Through the Lens Capsule}

The lens capsule compartmentalizes the lens cells from direct contact with other ocular tissues and the surrounding aqueous and vitreous humors. The capsule has been proposed to be a barrier protecting the lens from bacterial and most viral infections (Beyer et al., 1984; Cotlier et al., 1968; Karkinen-Jaaskelainen et al., 1975) in addition to conferring immune privilege to the lens (Coulombre, 1979). It has been shown that fetal rubella infections resulting in cataract formation can only occur prior to the closure of the lens vesicle and formation of a continuous lens capsule (Cotlier et al., 1968; Karkinen-Jaaskelainen et al., 1975). Additionally, the posterior capsule is capable of protecting the posterior eye tissues from bacterial infections of the anterior chamber (Beyer et al., 1984). Despite this, adenovirus vectors (approximate 
diameter of 70-130 nm) injected into the aqueous chamber in vivo can transduce lens epithelial cells but only with very high vector concentrations and even then at a one thousand fold lower transduction efficiency than observed in ciliary tissue (Borras et al., 1996; Budenz et al., 1995; Robertson et al., 2007).

Although these large infectious agents have a difficult time diffusing through the capsule, smaller molecules required for cell metabolism such as glucose, salts, water, $\mathrm{O}_{2}, \mathrm{CO}_{2}$, and the resulting metabolic waste all pass freely through the capsule and into the cortex and nucleus of the avascular lens (see Delemere review in this issue) (Fisher, 1977; Friedenwald, 1930a; Friedenwald, 1930b). Interestingly, the permeability of water and sugars through the lens capsules of bovines and rabbits decreases with age (Fels, 1970; Friedenwald, 1930a; Friedenwald, 1930b) however an association with the occurrence of cataract has not been established (Fisher, 1977; Friedenwald, 1930b).

Intermediate sized molecules (such as proteins) present in the aqueous and vitreous humors are also required for proper growth and development of the lens and must transit the lens capsule. Further, the lens produces proteins that must be released into the humors for appropriate development and homeostasis of the remainder of the eye. The lens capsule is thought to be selectively permeable to these molecules with the rate of their passage influenced by their size and charge. Overall, the distribution of heparan sulfate side chains and free carboxyl groups within the capsule matrix give it a net anionic charge (Friedenwald, 1930b; Winkler et al., 2001). In early qualitative studies, Jonas Friedenwald determined that the lens capsule was less permeable to intermediate size molecules with an anionic charge than ones with neutral or cationic charges (Friedenwald, 1930b). Partial masking or removal of these anionic sites in glomerular basement membranes results in an increase in permeability to proteins (Bertolatus and Hunsicker, 1987; Bridges et al., 1991; Kanwar et al., 1980; Morita et al., 2005), although this has not yet been explored in the lens capsule.

Proteins as large as albumin $(66 \mathrm{kDa})$, horse radish peroxidase $(40 \mathrm{kDa})$, the crystallins (20-1,200 kDa), and 4.7 Kb plasmids have been reported to enter lenses with intact capsules (Boyle et al., 2002; Lo and Harding, 1983; Sabah et al., 2005; Sabah et al., 2004). Additionally, phacotoxic uveitis, an ocular inflammatory condition associated with hypermature cataract in animals, appears to be caused by the release of lens crystallins through intact lens capsules (Coulter et al., 1999; van der Woerdt, 2000). Quantitatively, the diffusion rates of intermediate size molecules in the lens capsule differ based on molecular size. Neutral dextrans, which are highly branched polysaccharides, between $376 \mathrm{Da}$ and $147.8 \mathrm{kDa}$ diffuse through the lens capsule at rates directly correlated to their molecular weights (Lee et al., 2006). Conversely, proteins and molecules carrying a net negative charge, such as recombinant epidermal growth factor ( $\mathrm{pI}$ of 5.4) and single stranded DNA, have significantly slower diffusion rates than neutral dextrans of similar molecular weights (Danysh et al., 2008b). These data lead to the conclusion that molecular charge has a significant contribution to a molecule's diffusion rate through the lens capsule. However, much work is necessary to yield a comprehensive understanding of which molecules efficiently transit the capsule and the constraints placed upon those that do not.

\section{Biomechanical Properties of the Capsule}

Much of the historical work on biomechanical measurements of anterior and posterior lens capsules was reviewed in detail by Krag and Andreassen in 2003. Here we incorporate more recent studies and explain some of the terms used (Figures $4 \mathrm{a}-\mathrm{c}$ ) while emphasizing the significance of capsular biomechanics for a non-engineering audience.

The mechanical behavior of a tissue is generally studied in experiments where a sample is deformed in a controlled manner and the resulting reaction load, generated within the material, 
is measured. Conversely, a controlled load can be applied to the tissue and the resulting deformation measured. The experiment often continues until the tissue sample is damaged or fails. Deformation-controlled and load-controlled experiments result in data expressed as variations in load, expressed in Newtons $\left(\mathrm{N}\right.$ or $\mathrm{kg} / \mathrm{ms}^{2}$ ), and deformation, in millimeters ( $\mathrm{mm}$ ) (Figure 4a). Structural properties that describe the experimental results are determined for comparison across specimens, harvest location within the tissue, age or intervention. These include the ultimate load $(\mathrm{N})$ and the ultimate deformation $(\mathrm{mm})$ experienced by the tissue at failure. If a straight line can be fit to a portion of the load-deformation data, the linear slope of the relationship can be determined. This value is called the stiffness $(\mathrm{N} / \mathrm{mm})$. These structural parameters are a function of the geometry of the tissue sample, not the intrinsic properties of the material itself. As a result, a specimen made of the exact same material will have a greater ultimate load if it is thicker or larger in size. A specimen with a greater ultimate deformation may just be longer. Stiffness will be similarly affected by geometry. Because of this, the structural behavior is normalized to account for differences in the dimensions of the tissues. This requires the ability to accurately measure the tissue geometry, as suggested in the lens capsule thickness section, but allows for comparisons among capsules of different thicknesses due to age, region along the lens, pathologies, and species. However, unnormalized data is perhaps more practically useful in developing surgical techniques and accommodative IOLs.

Load is normalized by dividing it by the cross sectional area perpendicular to the direction of load application (capsule thickness), resulting in the normal stress in Pascals $(\mathrm{Pa})$ with the units of Newtons per millimeter squared $\left(\mathrm{N} / \mathrm{mm}^{2}\right)$. Deformation is normalized by dividing the length of the material after loading (measured in the direction of loading) by the original length of the material, to yield the engineering strain. Strain is unitless (length over length) or presented as a percentage value. The load-deformation relationship is then normalized to the stress-strain relationship and the intrinsic material properties determined (Figure $4 \mathrm{~b}$ ). These include the ultimate stress (also called ultimate strength, in $\mathrm{Pa}$ or $\mathrm{N} / \mathrm{mm}^{2}$ ) and ultimate elongation (\%) which are defined at the point of material failure in a loading experiment. The stiffness becomes normalized to the elastic modulus, a ratio of stress over strain (or Young's modulus in Pa or $\mathrm{N} / \mathrm{mm}^{2}$ ). Materials with a higher elastic modulus require more stress than materials with a lower elastic modulus to achieve the same percent of strain. The area under the stress-strain curve is a representation of how much energy the tissue can absorb before failure, which is called the toughness (in $\mathrm{Pa}$ or $\mathrm{N} / \mathrm{mm}^{2}$ ).

Krag and Andreassen harvested uniform circular specimens from different capsular regions using laser dissection. The ring specimens were wrapped around pegs attached to an actuator and uniaxial tests were performed by loading them with tension until failure. As with most biological soft tissues, the stress-strain relationship shows a bi-linear response with an initial region of high strain resulting from little stress and a second region when the tissue becomes stiffer, requiring more stress to increase strain (Krag et al., 1997). A representation of stressstrain data with two elastic moduli regions is shown in Figure 4b. A third region of sub-failure response may be present where the stress-strain curves vary wildly preceding failure.

Stiffnesses and elastic moduli can be determined for each of the first two regions or the entire curve modeled as with an exponential equation. It is thought that during uniaxial stress tests the collagen IV network's polygonal structure is initially straightened during the first region and then become fully loaded in the second (Burd, 2008). Individual matrix bonds or tissue layers begin breaking during the third region and quickly transfer their stress to adjoining tissue until all the structure fails. In tests using biaxial loads, the collagen IV network does not undergo the initial straightening and would be cause for differences when comparing stress-strain responses to uniaxial tests (Burd, 2008).

Uniaxial tests demonstrate structural and material properties vary at different locations and with aging in the lens capsule. The ultimate load of the anterior capsule is three to seven times 
higher than the posterior capsule (Krag and Andreassen, 2003b). This is directly correlated to the difference in thicknesses between the anterior and posterior capsules. The ultimate load for human lens capsules decreases throughout life in both the anterior and posterior capsules (Krag and Andreassen, 2003b). Ultimate stress in the human anterior lens capsule decreases approximately $1 \%$ each year throughout life, ranging from 17.5 to $1.5 \mathrm{~N} / \mathrm{mm}^{2}$ (7 month to 97 year old donors) with a similar decline in the posterior capsule (Krag and Andreassen, 2003b; Krag et al., 1997). In the posterior capsule, the decline begins at a slightly earlier age (Fisher, 1969a; Krag and Andreassen, 2003b). Interestingly, about 30\% of lens capsules from patients older than 75 years old experienced a sub-failure damage event prior to complete failure in the load-deformation curve (Krag et al., 1997). This is attributed to a partial delamination of the capsule into two layers within some of the older lens capsules. The toughness of the lens capsule also decreases steadily with age, approximately $0.8 \%$ per year (Krag et al., 1997). These decreases in failure and toughness values in older patients are of great concern to cataract surgeons, who usually apply loads greater than those the capsule experiences through accommodative forces (Krag and Andreassen, 2003a). This should be of particular significance while performing cataract surgery on patients with pseudoexfoliative glaucoma (Fine and Hoffman, 1997) or mature cataracts (Natchiar et al., 1993) since in both cases the lens capsule is more friable and subject to rupture.

The stress-strain response of the anterior lens capsule is bilinear and the first elastic modulus region represents capsular strains up to $10 \%$ of the initial length. This lies in the presumed range of deformation experienced by the capsule under accommodative forces (Fincham, 1937; Fisher, 1969a). Under uniaxial load, capsular elastic moduli at 10\% strain increase with age until about age 35 , from 0.3 to $2.3 \mathrm{~N} / \mathrm{mm}^{2}$, and then are relatively constant (Krag and Andreassen, 2003a). These values are similar for both the posterior and anterior capsule poles (Krag and Andreassen, 2003b). The second elastic modulus region of the stress-strain curve describes strains the capsule would experience beyond normal accommodative forces, from $20 \%$ to $>40 \%$ (point of failure). In this region, under both uniaxial and biaxial loading experiments, the elastic moduli decrease throughout life, from approximately $6 \mathrm{~N} / \mathrm{mm}^{2}$ at birth to $2 \mathrm{~N} / \mathrm{mm}^{2}$ (Fisher, 1969a; Krag et al., 1997). Biaxial loading on different regions of the anterior capsule demonstrate a gradient of increasing stiffness moving from the anterior pole toward the equatorial region (Pedrigi et al., 2007a). The ratio of elasticity in the circumferential (parallel to the circumference) versus the meridional (perpendicular to the circumference) directions is nearly isotropic but becomes increasingly anisotropic towards the equatorial region as the circumferential direction becomes more elastic (David et al., 2007; Pedrigi et al., 2007a). Accommodative intraocular lenses often take advantage of the elastic properties of the lens capsule to return the lens to an unaccommodated state. Their design must take into consideration the plateauing of capsule elasticity in the accommodative force range and the decline in higher ranges (Weale, 2005).

The lens capsule also behaves as a viscoelastic material exhibiting a time-dependent mechanical response (Krag and Andreassen, 2003a; Thim et al., 1993). Viscoelastic materials recover to their original dimensions after being strained, but unlike ideal elastic materials, they will absorb energy during the recovery. The absorbed or lost energy is presumptively a result of the rearrangement of water and molecules within the capsule matrix during deformation. The behaviors that define viscoelasticity are rate-dependence, stress-relaxation, and creep. The lens capsule is rate-dependent in that it will have a larger stiffness or elastic modulus when loaded quickly compared to slowly. This is important to consider when comparing stiffnesses and elastic moduli from different experiments. Stress-relaxation is the stress response versus time after the application of a step strain to the tissue (constant strain applied). Initially the stress peaks and then reduces over time as a viscoelastic material relaxes. Stress-relaxation is recorded as the percent loss in stress over a specific time while a constant strain is applied (Figure 4c). Similarly, creep is the strain response versus time after the application of a step 
stress to the tissue (constant stress applied). The tissue will slowly strain after loading. The viscoelastic properties of the lens capsule have significance in designing cataract surgical techniques using viscoexpression of the lens cellular material, which induces fluid pressure within the capsular bag over time and takes advantage of the lens capsule's viscoelastic properties (Thim et al., 1993). The stress-relaxation measured in the human anterior lens capsule was $12 \%$ over 20 seconds after a $10 \%$ step strain is applied and $21 \%$ over 20 seconds after a $40 \%$ step strain is applied. Both stress-relaxation responses stay consistent with age (Krag and Andreassen, 2003a).

\section{The Effects of Non-Enzymatic Glycation on the Lens Capsule}

Hyperglycemia is a condition in which the blood contains high levels of glucose (such as in poorly managed diabetes). Long periods of exposure to high blood glucose levels can result in intramolecular and intermolecular cross-linking between lysine amine groups, termed nonenzymatic glycation (Bailey et al., 1993), altering a basement membrane's native structure and mechanical properties. Additionally, glycated lysines within specific domains interfere with protein binding and normal basement membrane-cell interactions affecting cellular signaling pathways (Hasegawa et al., 1995; Hong et al., 2000; Raabe et al., 1996). The extremely slow molecular turnover rates in the lens capsule make its structural molecules highly susceptible to the accumulative effects of this cross-linking (Bailey et al., 1993; Garlick et al., 1988; Raabe et al., 1996). In vitro experiments demonstrate that glycation of the NC1 domain of collagen IV monomers impairs the initiation of collagen IV protomer assembly (Tsilibary et al., 1988) and glycation of the triple helical domain of collagen IV monomers leads to a decrease in the stability of the protomer (Raabe et al., 1996); however, any impaired collagen IV protomer assembly does not affect established collagen IV networks (Bailey et al., 1993). Conversely, intermolecular cross-linking due to non-enzymatic glycation occurring between super-coiled and laterally aligned triple helical domains as well as adjoining 7S domains of collagen IV protomers result in more stiff and brittle lens capsules (Bailey et al., 1993; Raabe et al., 1996). Human lens capsules incubated in glucose show a concentration and exposure time dependent increase in capsular stiffness in all regions of the anterior capsule. This increase parallels the anisotropic stiffness gradient observed in normal anterior lens capsules in both the circumferential and meridional directions (Bailey et al., 1993; Pedrigi et al., 2007a; Pedrigi et al., 2007b).

\section{The Role of the Capsule in Lens Accommodation}

The accommodative mechanism in primates involves alterations in the curvature of the anterior lens surface, changing the optical power of the lens. Variations in radial tension applied to the zonules through the relaxation and contraction of ciliary muscles are transmitted to a compliant lens substance via the lens capsule, changing the shape. In a fully disaccommodated state (far focused eye), in which the ciliary muscles relax and move away from the lens, radial tension is applied through all of the zonules (Schachar, 1994; Schachar, 2006) stressing the lens capsule at the zonule attachment points around the equatorial region. Recently, optical coherence tomography studies demonstrate there is a significant increase in capsular stress at the anterior pole while the lens is in a disaccommodative state (Schachar and Koivula, 2008). These forces spatially vary the curvature of the anterior surface, flattening the anterior periphery more than the anterior pole. A relatively flat anterior lens surface is considered to be the natural curvature of the primate lens since it takes on a similar shape when the capsule is removed (Fincham, 1937; Glasser and Campbell, 1999). In a fully accommodated state (near focused eye), the ciliary muscles contract moving the ciliary process both anteriorly and towards the lens. This movement releases the radial tension on the anterior and posterior zonules while increasing the radial tension on the equatorial zonules (Schachar, 1994; Schachar, 2006). The release of radial tension on the anterior and posterior zonules allow the stored strain energy in the lens 
capsule to apply stress to the lens material, reshaping the lens and increasing the curvature of the anterior surface as well as thickening the lens axially. This reshaping results from a reorganization of the lens cortical fibers and nucleus (Koretz and Handelman, 1982). Coordinated sliding of the fiber cell basal and apical tips (Kuszak et al., 2006) gives the lens the ability to mold around the shape of the lens nucleus (Brown, 1973; Koretz et al., 2002).

The precise role of the lens capsule in the accommodative mechanism and how the forces applied by the lens capsule reshape the lens material is not completely understood. The elastic modulus of the lens capsule must be sufficiently higher than that of the lens substance to allow the forces applied by the ciliary muscles to mold the lens shape. The adult human capsule has an elastic modulus approximately two thousand times higher than the cellular lens cortex and nucleus it surrounds, 1.2, 3.2 $\times 10^{-3}$, and $0.6 \times 10^{-3} \mathrm{~N} / \mathrm{mm}^{2}$ respectively (Fisher, 1971; Krag and Andreassen, 1996). Since thicker elastic materials are more effective in distributing forces, it had been hypothesized that the varied thickness of the capsule actively molds the lens to its appropriate shape during accommodation (Fincham, 1937). However, it is now thought that the lens capsule simply serves as a force distributor, evenly applying stored elastic energy over the surface of the lens. First, the anterior and posterior capsule thickness variations observed in adult lenses are also seen in animals whose lenses do not accommodate, and may arise from metabolic differences between the epithelial and fiber cells (Bhat, 2001). In this light, the regional thickness variations observed in the primate anterior capsule (Fincham, 1937) could simply be the result of stress-induced capsular remodeling. Second, the viscoelastic properties of the lens capsule have been proposed to be more suited for even transmission of forces over the lens surface making the capsule less likely to play more than an elastic force transmission role in lens molding (Krag and Andreassen, 2003a).

The ability of the human lens to accommodate decreases with age and is manifested in the onset of presbyopia (see Truscott review in this issue). How the lens capsule contributes to this decline, however, is unclear. A recent study measured stiffness by radially stretching human capsular bags within the accommodative range. Capsular bag stiffness, which does not account for the continual increase in capsule thickness, does not increase with age (Ziebarth et al., 2008). This is similar to uniaxial elastic modulus data of the human anterior and posterior capsules after the age of 35 (Krag and Andreassen, 1996; Krag and Andreassen, 2003b). Conversely, there is an increase in stiffness (Ziebarth et al., 2008) and elastic modulus (Fisher, 1971) observed in the lens nucleus and cortex resulting from the continual accession of fiber cells (Koretz et al., 1997). As the elastic modulus of the lens substance increases more force must be transmitted through the lens capsule to mold its shape. The inability of the lens capsule to achieve a sufficient elastic modulus over the lens substance in order to transmit the necessary accommodative forces may be a primary cause of presbyopia (Fisher, 1969b).

\section{Unanswered Scientific Questions}

It is obvious that the lens capsule is more than just an inert membrane surrounding the cells of the lens. Through its direct and indirect interactions with lens cell membrane receptors it has been shown to play an integral role in lens development and biology. However, much of the nature of these interactions and how they might contribute to the onset of cataract is still unknown. The characterization of the spatial and temporal variations in molecular isoforms, such as for laminin, that occur in the capsule is incomplete. It is also not fully known how these variations in molecular isoforms alter lens development and growth via their interactions with integrins. The reservoir of growth factors held by the capsule and the regulation of their release is also an area of great interest and still requires more exploration.

It is known that the capsule increases in area and thickness dramatically. However, nothing is known about how this area increase can occur since the core components of the capsule do not 
generally turn over during development while new capsule material is made by the cells it encloses. Further, the lens capsule must be interdigitated with zonules produced by the ciliary body during lens development, however, nothing is known about how the zonular apparatus is assembled or how this process is regulated. In addition, while many of the physical properties of the adult lens capsule have been determined, it is not clear what structural and molecular changes produce the gradual weakening seen in mature lens capsules. It is also not certain to what degree the lens capsule is selectively permeable to intermediate sized charged molecules and whether the distribution of anionic sites contributes to its permeability. Overall, the lens capsule is an understudied participant in lens biology and the explosion in our knowledge of other extracellular matrices in recent years makes this a fruitful topic of future investigation.

\section{Acknowledgements}

The preparation of this review was supported by National Eye Institute grant EY015279. We are grateful to Dr. John Novotny for critical reading of the manuscript.

\section{References}

Ammash NM, Sundt TM, Connolly HM. Marfan syndrome-diagnosis and management. Curr Probl Cardiol 2008;33:7-39. [PubMed: 18155514]

Aragon-Martin JA, Ritch R, Liebmann J, O'Brien C, Blaaow K, Mercieca F, Spiteri A, Cobb CJ, Damji KF, Tarkkanen A, Rezaie T, Child AH, Sarfarazi M. Evaluation of LOXL1 gene polymorphisms in exfoliation syndrome and exfoliation glaucoma. Mol Vis 2008;14:533-41. [PubMed: 18385788]

Aumailley M, Smyth N. The role of laminins in basement membrane function. J Anat 1998;193(Pt 1):121. [PubMed: 9758133]

Bader BL, Smyth N, Nedbal S, Miosge N, Baranowsky A, Mokkapati S, Murshed M, Nischt R. Compound Genetic Ablation of Nidogen 1 and 2 Causes Basement Membrane Defects and Perinatal Lethality in Mice. Mol. Cell. Biol 2005;25:6846-6856. [PubMed: 16024816]

Bailey AJ, Sims TJ, Avery NC, Miles CA. Chemistry of collagen cross-links: glucose-mediated covalent cross-linking of type-IV collagen in lens capsules. Biochem J 1993;296(Pt 2):489-96. [PubMed: 8257442]

Barraquer RI, Michael R, Abreu R, Lamarca J, Tresserra F. Human Lens Capsule Thickness as a Function of Age and Location along the Sagittal Lens Perimeter. Invest Ophthalmol Vis Sci 2006;47:20532060. [PubMed: 16639015]

Bassnett S, Missey H, Vucemilo I. Molecular architecture of the lens fiber cell basal membrane complex. J Cell Sci 1999;112(Pt 13):2155-65. [PubMed: 10362545]

Battaglia C, Mayer U, Aumailley M, Timpl R. Basement-membrane heparan sulfate proteoglycan binds to laminin by its heparan sulfate chains and to nidogen by sites in the protein core. Eur J Biochem 1992;208:359-66. [PubMed: 1521532]

Beavan L, Davies M, Couchman J, Williams M, Mason R. In vivo turnover of the basement membrane and other heparan sulfate proteoglycans of rat glomerulus. Arch Biochem Biophys 1989;269:576-585. [PubMed: 2521995]

Belford DA, Gole GA, Rush RA. Localization of laminin to retinal vessels of the rat and mouse using whole mounts. Invest Ophthalmol Vis Sci 1987;28:1761-6. [PubMed: 3312076]

Bertolatus JA, Hunsicker LG. Polycation binding to glomerular basement membrane. Effect of biochemical modification. Lab Invest 1987;56:170-9. [PubMed: 3807316]

Beyer TL, Vogler G, Sharma D, O'Donnell FE Jr. Protective barrier effect of the posterior lens capsule in exogenous bacterial endophthalmitis--an experimental primate study. Invest Ophthalmol Vis Sci 1984;25:108-12. [PubMed: 6607906]

Bhat SP. The ocular lens epithelium. Biosci Rep 2001;21:537-63. [PubMed: 11900326]

Blakely EA, Bjornstad KA, Chang PY, McNamara MP, Chang E, Aragon G, Lin SP, Lui G, Polansky JR. Growth and differentiation of human lens epithelial cells in vitro on matrix. Invest Ophthalmol Vis Sci 2000;41:3898-907. [PubMed: 11053292] 
Borras T, Tamm ER, Zigler JS Jr. Ocular adenovirus gene transfer varies in efficiency and inflammatory response. Invest Ophthalmol Vis Sci 1996;37:1282-93. [PubMed: 8641831]

Bose K, Nischt R, Page A, Bader BL, Paulsson M, Smyth N. Loss of nidogen-1 and -2 results in syndactyly and changes in limb development. J Biol Chem 2006;281:39620-9. [PubMed: 17023412]

Boyle DL, Carman P, Takemoto L. Translocation of macromolecules into whole rat lenses in culture. Mol Vis 2002;8:226-34. [PubMed: 12118240]

Brekken RA, Sage EH. SPARC, a matricellular protein: at the crossroads of cell-matrix. Matrix Biol 2000;19:569-80. [PubMed: 11102747]

Bridges CR Jr. Rennke HG, Deen WM, Troy JL, Brenner BM. Reversible hexadimethrine-induced alterations in glomerular structure and permeability. J Am Soc Nephrol 1991;1:1095-108. [PubMed: 1912408]

Brinker JM, Pegg MT, Howard PS, Kefalides NA. Immunochemical characterization of type IV procollagen from anterior lens capsule. Coll Relat Res 1985;5:233-44. [PubMed: 2412754]

Brown N. The change in shape and internal form of the lens of the eye on accommodation. Exp Eye Res 1973;15:441-59. [PubMed: 4702379]

Bruck SD. Long-term stability of intraocular lenses: literature review, assessment, and testing protocol. J Long Term Eff Med Implants 1993;3:333-50. [PubMed: 10146730]

Budenz DL, Bennett J, Alonso L, Maguire A. In vivo gene transfer into murine corneal endothelial and trabecular meshwork cells. Invest Ophthalmol Vis Sci 1995;36:2211-5. [PubMed: 7558714]

Burd HJ. A Structural Constitutive Model for the Human Lens Capsule. Biomech. Model. Mechanobiol. 2008

Bystrom B, Virtanen I, Rousselle P, Gullberg D, Pedrosa-Domellof F. Distribution of laminins in the developing human eye. Invest Ophthalmol Vis Sci 2006;47:777-85. [PubMed: 16505007]

Cammarata P, Cantu-Crouch D, Oakford L, Morrill A. Macromolecular Organization of Bovine Lens Capsule. Tissue Cell 1986;18:83-97. [PubMed: 3515629]

Canals M, Costa-Vila J, Potau JM, Merindano MD, Ruano D. Scanning electron microscopy of the human zonule of the lens (Zonula ciliaris). Acta Anat (Basel) 1996;157:309-14. [PubMed: 9259880]

Center EM, Polizotto RS. Etiology of the developing eye in myelencephalic blebs (my) mice. Histol Histopathol 1992;7:231-6. [PubMed: 1515706]

Chamberlain CG, McAvoy JW. Evidence that fibroblast growth factor promotes lens fibre differentiation. Curr Eye Res 1987;6:1165-9. [PubMed: 3665571]

Charonis AS, Tsilibary EC, Saku T, Furthmayr H. Inhibition of laminin self-assembly and interaction with type IV collagen by antibodies to the terminal domain of the long arm. J Cell Biol 1986;103:1689-97. [PubMed: 2430974]

Chen $\mathrm{CH}$, Hansma HG. Basement membrane macromolecules: insights from atomic force microscopy. J Struct Biol 2000;131:44-55. [PubMed: 10945969]

Cheng Y-S, Champliaud M-F, Burgeson RE, Marinkovich MP, Yurchenco PD. Self-assembly of Laminin Isoforms. J. Biol. Chem 1997;272:31525-31532. [PubMed: 9395489]

Chu CL, Goerges AL, Nugent MA. Identification of common and specific growth factor binding sites in heparan sulfate proteoglycans. Biochemistry 2005;44:12203-13. [PubMed: 16142919]

Colognato H, Yurchenco PD. Form and function: the laminin family of heterotrimers. Dev Dyn 2000;218:213-34. [PubMed: 10842354]

Colville D, Savige J, Morfis M, Ellis J, Kerr P, Agar J, Fasset R. Ocular manifestations of autosomal recessive Alport syndrome. Ophthalmic Genet 1997;18:119-28. [PubMed: 9361309]

Colville D, Wang YY, Jamieson R, Collins F, Hood J, Savige J. Absence of ocular manifestations in autosomal dominant Alport syndrome associated with haematological abnormalties. Ophthalmic Genet 2000;21:217-25. [PubMed: 11135492]

Colville DJ, Savige J. Alport syndrome. A review of the ocular manifestations. Ophthalmic Genet 1997;18:161-73. [PubMed: 9457747]

Cosgrove D, Meehan DT, Grunkemeyer JA, Kornak JM, Sayers R, Hunter WJ, Samuelson GC. Collagen COL4A3 knockout: a mouse model for autosomal Alport syndrome. Genes Dev 1996;10:2981-92. [PubMed: 8956999] 
Cotlier E, Fox J, Bohigian G, Beaty C, Du Pree A. Pathogenic effects of rubella virus on embryos and newborn rats. Nature 1968;217:38-40. [PubMed: 4865590]

Coulombre AJ. Cataractogenesis: developmental inputs and constraints. Ophthalmology 1979;86:1559_ 70. [PubMed: 575919]

Coulombre JL, Coulombre AJ. Lens development. V. Histological analysis of the mechanism of lens reconstitution from implants of lens epithelium. J Exp Zool 1971;176:15-24. [PubMed: 4925671]

Coulter JB 3rd, Phinizy JL, Hunnicutt RE, Baumgart MA, Hise EM, Marr LK. Effects of age, sex, cataract, and cataract surgery on serum gamma-crystallin concentration. Ophthalmic Res 1999;31:337-45. [PubMed: 10420118]

Csato W. Development and characterization of the lens capsule of mouse embryos (day 12 to day 19 of gestation). Z Mikrosk Anat Forsch 1989;103:971-84. [PubMed: 2626867]

Cvekl A, Duncan MK. Genetic and epigenetic mechanisms of gene regulation during lens development. Prog Retin Eye Res 2007;26:555-97. [PubMed: 17905638]

Cvekl A, Tamm ER. Anterior eye development and ocular mesenchyme: new insights from mouse models and human diseases. Bioessays 2004;26:374-86. [PubMed: 15057935]

Danysh B, Czymmek K, Olurin P, Sivak J, Duncan M. Contributions of mouse genetic background and age on anterior lens capsule thickness. The Anatomical Record. 2008aaccepted publication

Danysh, B.; Patel, T.; Edwards, D.; Czymmek, K.; Duncan, MK. Sulfate and Carboxyl Groups Within the Anterior Lens Capsule Regulates Diffusion and Interactions of Charged Proteins. The Association for Research in Vision and Ophthalmology; FT Lauderdale, FL: 2008b. Session \#233, Abstract\#1524

David G, Pedrigi RM, Heistand MR, Humphrey JD. Regional multiaxial mechanical properties of the porcine anterior lens capsule. J Biomech Eng 2007;129:97-104. [PubMed: 17227103]

De Arcangelis A, Mark M, Kreidberg J, Sorokin L, Georges-Labouesse E. Synergistic activities of alpha3 and alpha6 integrins are required during apical ectodermal ridge formation and organogenesis in the mouse. Development 1999;126:3957-68. [PubMed: 10433923]

de Iongh RU, Wederell E, Lovicu FJ, McAvoy JW. Transforming growth factor-beta-induced epithelialmesenchymal transition in the lens: a model for cataract formation. Cells Tissues Organs 2005;179:43-55. [PubMed: 15942192]

Dessau W, Adelmann BC, Timpl R. Identification of the sites in collagen alpha-chains that bind serum anti-gelatin factor (cold-insoluble globulin). Biochem J 1978;169:55-9. [PubMed: 629753]

Dong L, Chen Y, Lewis M, Hsieh JC, Reing J, Chaillet JR, Howell CY, Melhem M, Inoue S, Kuszak JR, DeGeest K, Chung AE. Neurologic defects and selective disruption of basement membranes in mice lacking entactin-1/nidogen-1. Lab Invest 2002;82:1617-30. [PubMed: 12480912]

Dono R, Texido G, Dussel R, Ehmke H, Zeller R. Impaired cerebral cortex development and blood pressure regulation in FGF-2-deficient mice. Embo J 1998;17:4213-25. [PubMed: 9687490]

Duncan MK, Kozmik Z, Cveklova K, Piatigorsky J, Cvekl A. Overexpression of PAX6(5a) in lens fiber cells results in cataract and upregulation of (alpha)5(beta)1 integrin expression. J Cell Sci 2000;113 (Pt 18):3173-85. [PubMed: 10954416]

Dunsmore SE, Martinez-Williams C, Goodman RA, Rannels DE. Turnover of fibronectin and laminin by alveolar epithelial cells. Am J Physiol 1995;269:L766-75. [PubMed: 8572238]

Dunsmore SE, Rannels DE. Turnover of extracellular matrix by type II pulmonary epithelial cells. Am J Physiol 1995;268:L336-46. [PubMed: 7864154]

Dunsmore SE, Rannels DE. Extracellular matrix biology in the lung. Am J Physiol 1996;270:L3-27. [PubMed: 8772523]

Farach-Carson MC, Brown AJ, Lynam M, Safran JB, Carson DD. A novel peptide sequence in perlecan domain IV supports cell adhesion, spreading and FAK activation. Matrix Biol 2008;27:150-60. [PubMed: 17997086]

Farach-Carson MC, Carson DD. Perlecan--a multifunctional extracellular proteoglycan scaffold. Glycobiology 2007;17:897-905. [PubMed: 17442708]

Fels IG. Permeability of the anterior bovine lens capsule. Exp Eye Res 1970;10:8-14. [PubMed: 5456784]

Fincham EF. The Mechanism of Accomodation. Br J Ophthalmol, Monograph Supplement VIII 1937;8:2-80. 
Fine IH, Hoffman RS. Phacoemulsification in the presence of pseudoexfoliation: challenges and options. J Cataract Refract Surg 1997;23:160-5. [PubMed: 9113564]

Fisher RF. Elastic constants of the human lens capsule. J Physiol 1969a;201:1-19. [PubMed: 5773553]

Fisher RF. The significance of the shape of the lens and capsular energy changes in accommodation. J Physiol 1969b;201:21-47. [PubMed: 5775812]

Fisher RF. The elastic constants of the human lens. J Physiol 1971;212:147-80. [PubMed: 5101807]

Fisher RF. Changes in the permeability of the lens capsule in senile cataract. Trans Ophthalmol Soc U K 1977;97:100-3. [PubMed: 271370]

Fisher RF, Pettet BE. The postnatal growth of the capsule of the human crystalline lens. J Anat 1972;112:207-214. [PubMed: 5077192]

Fox JW, Mayer U, Nischt R, Aumailley M, Reinhardt D, Wiedemann H, Mann K, Timpl R, Krieg T, Engel J, et al. Recombinant nidogen consists of three globular domains and mediates binding of laminin to collagen type IV. Embo J 1991;10:3137-46. [PubMed: 1717261]

Francisco-Morcillo J, Sanchez-Calderon H, Kawakami Y, Belmonte JC, Hidalgo-Sanchez M, MartinPartido G. Expression of Fgf19 in the developing chick eye. Brain Res Dev Brain Res 2005;156:1049.

Friedenwald J. The Permeability of the Lens Capsule to Water, Dextrose, and Other Sugars. Arch Ophthalmol 1930a;4:350-360.

Friedenwald J. Permeability of the lens capsule with special reference to the etiology of senile cataract. Arch Ophthalmol 1930b;3:182-193.

Fuerst PG, Rauch SM, Burgess RW. Defects in eye development in transgenic mice overexpressing the heparan sulfate proteoglycan agrin. Dev Biol 2007;303:165-80. [PubMed: 17196957]

Fukai N, Eklund L, Marneros AG, Oh SP, Keene DR, Tamarkin L, Niemela M, Ilves M, Li E, Pihlajaniemi T, Olsen BR. Lack of collagen XVIII/endostatin results in eye abnormalities. Embo J 2002;21:153544. [PubMed: 11927538]

Fukushi S, Spiro RG. The lens capsule. Sugar and amino acid composition. J Biol Chem 1969;244:20418. [PubMed: 5781998]

Garlick RL, Bunn HF, Spiro RG. Nonenzymatic glycation of basement membranes from human glomeruli and bovine sources. Effect of diabetes and age. Diabetes 1988;37:1144-50. [PubMed: 3134265]

Garner A, Alexander RA. Histochemistry of elastic and related fibres in the human eye in health and disease. Histochem J 1986;18:405-12. [PubMed: 3781873]

Gautam M, DeChiara TM, Glass DJ, Yancopoulos GD, Sanes JR. Distinct phenotypes of mutant mice lacking agrin, MuSK, or rapsyn. Brain Res Dev Brain Res 1999;114:171-8.

Gay S, Miller EJ. Characterization of lens capsule collagen: evidence for the presence of two unique chains in molecules derived from major basement membrane structures. Arch Biochem Biophys 1979;198:370-8. [PubMed: 518091]

Gersdorff N, Otto S, Roediger M, Kruegel J, Miosge N. The absence of one or both nidogens does not alter basement membrane composition in adult murine kidney. Histol Histopathol 2007;22:1077-84. [PubMed: 17616934]

Gilmour DT, Lyon GJ, Carlton MB, Sanes JR, Cunningham JM, Anderson JR, Hogan BL, Evans MJ, Colledge WH. Mice deficient for the secreted glycoprotein SPARC/osteonectin/BM40 develop normally but show severe age-onset cataract formation and disruption of the lens. Embo $\mathrm{J}$ 1998;17:1860-70. [PubMed: 9524110]

Glasser A, Campbell MC. Biometric, optical and physical changes in the isolated human crystalline lens with age in relation to presbyopia. Vision Res 1999;39:1991-2015. [PubMed: 10343784]

Goldblum SE, Ding X, Funk SE, Sage EH. SPARC (secreted protein acidic and rich in cysteine) regulates endothelial cell shape and barrier function. Proc Natl Acad Sci U S A 1994;91:3448-52. [PubMed: 8159767]

Gould DB, Marchant JK, Savinova OV, Smith RS, John SW. Col4a1 mutation causes endoplasmic reticulum stress and genetically modifiable ocular dysgenesis. Hum Mol Genet 2007;16:798-807. [PubMed: 17317786]

Greenburg G, Hay ED. Epithelia suspended in collagen gels can lose polarity and express characteristics of migrating mesenchymal cells. J Cell Biol 1982;95:333-9. [PubMed: 7142291] 
Guthoff R, Abramo F, Draeger J, Chumbley L. Measurement of elastic resisting forces of intraocular haptic loops of varying geometrical designs and material composition. J Cataract Refract Surg 1990;16:551-8. [PubMed: 2231368]

Haddad A, Bennett G. Synthesis of lens capsule and plasma membrane glycoproteins by lens epithelial cells and fibers in the rat. Am J Anat 1988;183:212-25. [PubMed: 3213827]

Hallmann R, Horn N, Selg M, Wendler O, Pausch F, Sorokin LM. Expression and function of laminins in the embryonic and mature vasculature. Physiol Rev 2005;85:979-1000. [PubMed: 15987800]

Handler M, Yurchenco PD, Iozzo RV. Developmental expression of perlecan during murine embryogenesis. Dev Dyn 1997;210:130-45. [PubMed: 9337134]

Hanssen E, Franc S, Garrone R. Synthesis and structural organization of zonular fibers during development and aging. Matrix Biol 2001;20:77-85. [PubMed: 11334709]

Hansson HA. Scanning electron microscopy of the zonular fibers in the rat eye. Z Zellforsch Mikrosk Anat 1970;107:199-209. [PubMed: 5447673]

Hasegawa G, Hunter AJ, Charonis AS. Matrix nonenzymatic glycosylation leads to altered cellular phenotype and intracellular tyrosine phosphorylation. J Biol Chem 1995;270:3278-83. [PubMed: 7531703]

Hausser HJ, Ruegg MA, Brenner RE, Ksiazek I. Agrin is highly expressed by chondrocytes and is required for normal growth. Histochem Cell Biol 2007;127:363-74. [PubMed: 17186266]

Henry MD, Campbell KP. A role for dystroglycan in basement membrane assembly. Cell 1998;95:85970. [PubMed: 9865703]

Hodgkinson LM, Duncan G, Wang L, Pennington CJ, Edwards DR, Wormstone IM. MMP and TIMP expression in quiescent, dividing, and differentiating human lens cells. Invest Ophthalmol Vis Sci 2007;48:4192-9. [PubMed: 17724206]

Hong SB, Lee KW, Handa JT, Joo CK. Effect of advanced glycation end products on lens epithelial cells in vitro. Biochem Biophys Res Commun 2000;275:53-9. [PubMed: 10944440]

Hopf M, Gohring W, Kohfeldt E, Yamada Y, Timpl R. Recombinant domain IV of perlecan binds to nidogens, laminin-nidogen complex, fibronectin, fibulin-2 and heparin. Eur J Biochem 1999;259:917-25. [PubMed: 10092882]

NEIBank. National Eye Institute, US Department of Health and Human Services. 2008. http://neibank.nei.nih.gov

Hunt HH. A study of the fine structure of the optic vesicle and lens placode of the chick embryo during induction. Dev Biol 1961;3:175-209. [PubMed: 13716849]

Iozzo RV. Heparan sulfate proteoglycans: intricate molecules with intriguing functions. J Clin Invest 2001;108:165-7. [PubMed: 11457866]

Iozzo RV. Basement membrane proteoglycans: from cellar to ceiling. Nat Rev Mol Cell Biol 2005;6:64656. [PubMed: 16064139]

Jefferson JA, Lemmink HH, Hughes AE, Hill CM, Smeets HJ, Doherty CC, Maxwell AP. Autosomal dominant Alport syndrome linked to the type IV collage alpha 3 and alpha 4 genes (COL4A3 and COL4A4). Nephrol Dial Transplant 1997;12:1595-9. [PubMed: 9269635]

Johansson S, Svineng G, Wennerberg K, Armulik A, Lohikangas L. Fibronectin-integrin interactions. Front Biosci 1997;2:d126-46. [PubMed: 9159220]

Johnson MC, Beebe DC. Growth, synthesis and regional specialization of the embryonic chicken lens capsule. Exp Eye Res 1984;38:579-92. [PubMed: 6468538]

Kanwar YS, Linker A, Farquhar MG. Increased permeability of the glomerular basement membrane to ferritin after removal of glycosaminoglycans (heparan sulfate) by enzyme digestion. J Cell Biol 1980;86:688-693. [PubMed: 6447156]

Karkinen-Jaaskelainen M, Saxen L, Vaheri A, Leinikki P. Rubella cataract in vitro: Sensitive period of the developing human lens. J Exp Med 1975;141:1238-48. [PubMed: 1092795]

Kefalides NA, Borel JP. Internal Organization of Basement Membranes. Current Topics in Membranes 2005;56:265-285.

Kelley P, Sabo Y, Duncan M. Collagen IV in the developing lens capsule. Matrix Biol 2002;21:415-423. [PubMed: 12225806] 
Kleppel MM, Michael AF. Expression of novel basement membrane components in the developing human kidney and eye. Am J Anat 1990;187:165-74. [PubMed: 2301276]

Kleppel MM, Santi PA, Cameron JD, Wieslander J, Michael AF. Human tissue distribution of novel basement membrane collagen. Am J Pathol 1989;134:813-25. [PubMed: 2650557]

Kohfeldt E, Sasaki T, Gohring W, Timpl R. Nidogen-2: a new basement membrane protein with diverse binding properties. J Mol Biol 1998;282:99-109. [PubMed: 9733643]

Kohno T, Sorgente N, Ishibashi T, Goodnight R, Ryan SJ. Immunofluorescent studies of fibronectin and laminin in the human eye. Invest Ophthalmol Vis Sci 1987;28:506-14. [PubMed: 3549611]

Koretz JF, Cook CA, Kaufman PL. Accommodation and presbyopia in the human eye. Changes in the anterior segment and crystalline lens with focus. Invest Ophthalmol Vis Sci 1997;38:569-78. [PubMed: 9071209]

Koretz JF, Cook CA, Kaufman PL. Aging of the human lens: changes in lens shape upon accommodation and with accommodative loss. J Opt Soc Am A Opt Image Sci Vis 2002;19:144-51. [PubMed: 11778717]

Koretz JF, Handelman GH. Model of the accommodative mechanism in the human eye. Vision Res 1982;22:917-27. [PubMed: 7135854]

Krag S, Andreassen TT. Biomechanical measurements of the porcine lens capsule. Exp Eye Res 1996;62:253-60. [PubMed: 8690034]

Krag S, Andreassen TT. Mechanical properties of the human lens capsule. Prog Retin Eye Res 2003a; 22:749-67. [PubMed: 14575723]

Krag S, Andreassen TT. Mechanical Properties of the Human Posterior Lens Capsule. Invest Ophthalmol Vis Sci 2003b;44:691-696. [PubMed: 12556400]

Krag S, Olsen T, Andreassen TT. Biomechanical characteristics of the human anterior lens capsule in relation to age. Invest Ophthalmol Vis Sci 1997;38:357-363. [PubMed: 9040468]

Krag S, Thim K, Corydon L. Strength of the lens capsule during hydroexpression of the nucleus. J Cataract Refract Surg 1993;19:205-8. [PubMed: 8487161]

Kramer JM. Basement membranes. WormBook 2005:1-15. [PubMed: 18050423]

Kreuger J, Jemth P, Sanders-Lindberg E, Eliahu L, Ron D, Basilico C, Salmivirta M, Lindahl U. Fibroblast growth factors share binding sites in heparan sulphate. Biochem J 2005;389:145-50. [PubMed: 15769253]

Kuhn K. Basement membrane (type IV) collagen. Matrix Biol 1995;14:439-45. [PubMed: 7795882]

Kurkinen M, Alitalo K, Vaheri A, Stenman S, Saxen L. Fibronectin in the development of embryonic chick eye. Dev Biol 1979;69:589-600. [PubMed: 437354]

Kurose H, Bito T, Adachi T, Shimizu M, Noji S, Ohuchi H. Expression of Fibroblast growth factor 19 (Fgf19) during chicken embryogenesis and eye development, compared with Fgf15 expression in the mouse. Gene Expr Patterns 2004;4:687-93. [PubMed: 15465490]

Kurose H, Okamoto M, Shimizu M, Bito T, Marcelle C, Noji S, Ohuchi H. FGF19-FGFR4 signaling elaborates lens induction with the FGF8-L-Maf cascade in the chick embryo. Dev Growth Differ 2005;47:213-23. [PubMed: 15921496]

Kuszak JR, Mazurkiewicz M, Jison L, Madurski A, Ngando A, Zoltoski RK. Quantitative analysis of animal model lens anatomy: accommodative range is related to fiber structure and organization. Vet Ophthalmol 2006;9:266-80. [PubMed: 16939454]

Lamanna WC, Kalus I, Padva M, Baldwin RJ, Merry CL, Dierks T. The heparanome--the enigma of encoding and decoding heparan sulfate sulfation. J Biotechnol 2007;129:290-307. [PubMed: 17337080]

Landemore G, Stefani P, Quillec M, Lecoq-Guilbert P, Billotte C, Izard J. Uneven distribution and size of rabbit lens capsule proteoglycans. Histochem J 1999;31:161-7. [PubMed: 10421415]

Lang RA. Pathways regulating lens induction in the mouse. Int J Dev Biol 2004;48:783-91. [PubMed: 15558471]

Laurent M, Lonchampt MO, Regnault F, Tassin J, Courtois Y. Biochemical, ultrastructural and immunological study of in vitro production of collagen by bovine lens epithelial cells in culture. Exp Cell Res 1978;115:127-42. [PubMed: 210028] 
Laurie GW, Bing JT, Kleinman HK, Hassell JR, Aumailley M, Martin GR, Feldmann RJ. Localization of binding sites for laminin, heparan sulfate proteoglycan and fibronectin on basement membrane (type IV) collagen. J Mol Biol 1986;189:205-16. [PubMed: 2946868]

Laurie GW, Leblond CP, Martin GR. Light microscopic immunolocalization of type IV collagen, laminin, heparan sulfate proteoglycan, and fibronectin in the basement membranes of a variety of rat organs. Am J Anat 1983;167:71-82. [PubMed: 6346854]

Lebel SP, Chen Y, Gingras D, Chung AE, Bendayan M. Morphofunctional studies of the glomerular wall in mice lacking entactin-1. J Histochem Cytochem 2003;51:1467-78. [PubMed: 14566019]

Lee CJ, Vroom JA, Fishman HA, Bent SF. Determination of human lens capsule permeability and its feasibility as a replacement for Bruch's membrane. Biomaterials 2006;27:1670-1678. [PubMed: 16199085]

Lee EH, Joo CK. Role of transforming growth factor-beta in transdifferentiation and fibrosis of lens epithelial cells. Invest Ophthalmol Vis Sci 1999;40:2025-32. [PubMed: 10440257]

Lee J, Gross JM. Laminin \{beta 1 and \{gamma 1 Containing Laminins Are Essential for Basement Membrane Integrity in the Zebrafish Eye. Invest. Ophthalmol. Vis. Sci 2007;48:2483-2490. [PubMed: 17525174]

Li S, Harrison D, Carbonetto S, Fassler R, Smyth N, Edgar D, Yurchenco PD. Matrix assembly, regulation, and survival functions of laminin and its receptors in embryonic stem cell differentiation. J Cell Biol 2002;157:1279-90. [PubMed: 12082085]

Lo WK, Harding CV. Tight junctions in the lens epithelia of human and frog: freeze-fracture and protein tracer studies. Invest Ophthalmol Vis Sci 1983;24:396-402. [PubMed: 6601087]

Lovicu FJ, McAvoy JW. Localization of acidic fibroblast growth factor, basic fibroblast growth factor, and heparan sulphate proteoglycan in rat lens: implications for lens polarity and growth patterns. Invest Ophthalmol Vis Sci 1993;34:3355-65. [PubMed: 7693608]

Lovicu FJ, McAvoy JW. Growth factor regulation of lens development. Dev Biol 2005;280:1-14. [PubMed: 15766743]

Lovicu, FJ.; Robinson, ML. Development of the ocular lens. Cambridge University Press, Cambridge, UK; New York: 2004. p. xvp. 398

Lu JY, Mohammed TA, Donohue ST, Al-Ghoul KJ. Distribution of basal membrane complex components in elongating lens fibers. Mol Vis 2008;14:1187-203. [PubMed: 18596883]

Marneros AG, Keene DR, Hansen U, Fukai N, Moulton K, Goletz PL, Moiseyev G, Pawlyk BS, Halfter W, Dong S, Shibata M, Li T, Crouch RK, Bruckner P, Olsen BR. Collagen XVIII/endostatin is essential for vision and retinal pigment epithelial function. EMBO J 2004;23:89-99. [PubMed: 14685281]

Marneros AG, Olsen BR. Physiological role of collagen XVIII and endostatin. FASEB J 2005;19:71628. [PubMed: 15857886]

Mayer U, Aumailley M, Mann K, Timpl R, Engel J. Calcium-dependent binding of basement membrane protein BM-40 (osteonectin, SPARC) to basement membrane collagen type IV. Eur J Biochem 1991;198:141-50. [PubMed: 2040276]

McAvoy JW. The spatial relationship between presumptive lens and optic vesicle/cup during early eye morphogenesis in the rat. Exp Eye Res 1981;33:447-58. [PubMed: 7197633]

McAvoy JW, Chamberlain CG. Fibroblast growth factor (FGF) induces different responses in lens epithelial cells depending on its concentration. Development 1989;107:221-8. [PubMed: 2632221]

Menko S, Philp N, Veneziale B, Walker J. Integrins and development: how might these receptors regulate differentiation of the lens. Ann N Y Acad Sci 1998;842:36-41. [PubMed: 9599291]

Miller DL, Ortega S, Bashayan O, Basch R, Basilico C. Compensation by fibroblast growth factor 1 (FGF1) does not account for the mild phenotypic defects observed in FGF2 null mice. Mol Cell Biol 2000;20:2260-8. [PubMed: 10688672]

Miner JH, Sanes JR. Molecular and functional defects in kidneys of mice lacking collagen alpha 3(IV): implications for Alport syndrome. J Cell Biol 1996;135:1403-13. [PubMed: 8947561]

Miosge N, Simniok T, Sprysch P, Herken R. The collagen type XVIII endostatin domain is co-localized with perlecan in basement membranes in vivo. J Histochem Cytochem 2003;51:285-96. [PubMed: 12588956] 
Mir S, Wheatley HM, Hussels IE, Whittum-Hudson JA, Traboulsi EI. A comparative histologic study of the fibrillin microfibrillar system in the lens capsule of normal subjects and subjects with Marfan syndrome. Invest Ophthalmol Vis Sci 1998;39:84-93. [PubMed: 9430549]

Mongiat M, Sweeney SM, San Antonio JD, Fu J, Iozzo RV. Endorepellin, a novel inhibitor of angiogenesis derived from the $C$ terminus of perlecan. J Biol Chem 2003;278:4238-49. [PubMed: 12435733]

Morita H, Yoshimura A, Inui K, Ideura T, Watanabe H, Wang L, Soininen R, Tryggvason K. Heparan sulfate of perlecan is involved in glomerular filtration. J Am Soc Nephrol 2005;16:1703-10. [PubMed: 15872080]

Mossbock G, Renner W, Faschinger C, Schmut O, Wedrich A, Weger M. Lysyl oxidase-like protein 1 (LOXL1) gene polymorphisms and exfoliation glaucoma in a Central European population. Mol Vis 2008;14:857-61. [PubMed: 18483563]

Mott JD, Werb Z. Regulation of matrix biology by matrix metalloproteinases. Curr Opin Cell Biol 2004;16:558-64. [PubMed: 15363807]

Muraoka M, Hayashi T. Three polypeptides with distinct biochemical properties are major alpha chainsize components of type IV collagen in bovine lens capsule. J Biochem 1993;114:358-62. [PubMed: 8282726]

Murshed M, Smyth N, Miosge N, Karolat J, Krieg T, Paulsson M, Nischt R. The absence of nidogen 1 does not affect murine basement membrane formation. Mol Cell Biol 2000;20:7007-12. [PubMed: 10958695]

Nakayama Y, Miyake A, Nakagawa Y, Mido T, Yoshikawa M, Konishi M, Itoh N. Fgf19 is required for zebrafish lens and retina development. Dev Biol 2008;313:752-66. [PubMed: 18089288]

Natchiar G, Robin AL, Nalgirkar AR, Krishnadas R. Posterior capsule tears during extracapsular cataract surgery in India. Arch Ophthalmol 1993;111:706-8. [PubMed: 8489458]

Naumann GO, Schlotzer-Schrehardt U, Kuchle M. Pseudoexfoliation syndrome for the comprehensive ophthalmologist. Intraocular and systemic manifestations. Ophthalmology 1998;105:951-68. [PubMed: 9627642]

Noakes PG, Miner JH, Gautam M, Cunningham JM, Sanes JR, Merlie JP. The renal glomerulus of mice lacking s-laminin/laminin beta 2: nephrosis despite molecular compensation by laminin beta 1 . Nat Genet 1995;10:400-6. [PubMed: 7670489]

Oh E, Pierschbacher M, Ruoslahti E. Deposition of plasma fibronectin in tissues. Proc Natl Acad Sci U S A 1981;78:3218-21. [PubMed: 6789333]

Oharazawa H, Ibaraki N, Lin LR, Reddy VN. The effects of extracellular matrix on cell attachment, proliferation and migration in a human lens epithelial cell line. Exp Eye Res 1999;69:603-10. [PubMed: 10620389]

Olitsky SE, Waz WR, Wilson ME. Rupture of the anterior lens capsule in Alport syndrome. J Aapos 1999;3:381-2. [PubMed: 10613586]

Olivero DK, Furcht LT. Type IV collagen, laminin, and fibronectin promote the adhesion and migration of rabbit lens epithelial cells in vitro. Invest Ophthalmol Vis Sci 1993;34:2825-34. [PubMed: 8360016]

Parks WC, Shapiro SD. Matrix metalloproteinases in lung biology. Respir Res 2001;2:10-9. [PubMed: 11686860]

Parmigiani C, McAvoy J. Localisation of laminin and fibronectin during rat lens morphogenesis. Differentiation 1984;28:53-61. [PubMed: 6394411]

Parmigiani CM, McAvoy JW. A morphometric analysis of the development of the rat lens capsule. Curr Eye Res 1989;8:1271-7. [PubMed: 2697512]

Parmigiani CM, McAvoy JW. The roles of laminin and fibronectin in the development of the lens capsule. Curr Eye Res 1991;10:501-11. [PubMed: 1893767]

Pedchenko V, Zent R, Hudson BG. Alpha(v)beta3 and alpha(v)beta5 integrins bind both the proximal RGD site and non-RGD motifs within noncollagenous (NC1) domain of the alpha3 chain of type IV collagen: implication for the mechanism of endothelia cell adhesion. J Biol Chem 2004;279:2772-80. [PubMed: 14610079]

Pedrigi RM, David G, Dziezyc J, Humphrey JD. Regional mechanical properties and stress analysis of the human anterior lens capsule. Vision Res 2007a;47:1781-9. [PubMed: 17467027] 
Pedrigi RM, Staff E, David G, Glenn S, Humphrey JD. Altered multiaxial mechanical properties of the porcine anterior lens capsule cultured in high glucose. J Biomech Eng 2007b;129:121-5. [PubMed: 17227107]

Pei YF, Rhodin JA. The prenatal development of the mouse eye. Anat Rec 1970;168:105-25. [PubMed: 5469558]

Perrimon N, Bernfield M. Specificities of heparan sulphate proteoglycans in developmental processes. Nature 2000;404:725-8. [PubMed: 10783877]

Peterson PE, Pow CS, Wilson DB, Hendrickx AG. Localisation of glycoproteins and glycosaminoglycans during early eye development in the macaque. J Anat 1995;186(Pt 1):31-42. [PubMed: 7649817]

Poschl E, Schlotzer-Schrehardt U, Brachvogel B, Saito K, Ninomiya Y, Mayer U. Collagen IV is essential for basement membrane stability but dispensable for initiation of its assembly during early development. Development 2004;131:1619-28. [PubMed: 14998921]

Raabe HM, Molsen H, Mlinaric SM, Acil Y, Sinnecker GH, Notbohm H, Kruse K, Muller PK. Biochemical alterations in collagen IV induced by in vitro glycation. Biochem J 1996;319(Pt 3): 699-704. [PubMed: 8920969]

Rafferty NS, Goossens W. Cytoplasmic filaments in the crystalline lens of various species: functional correlations. Exp Eye Res 1978;26:177-90. [PubMed: 305361]

Ramage IJ, Howatson AG, McColl JH, Maxwell H, Murphy AV, Beattie TJ. Glomerular basement membrane thickness in children: A stereologic assessment. Kidney Int 2002;62:895-900. [PubMed: 12164871]

Robertson JV, Nathu Z, Najjar A, Dwivedi D, Gauldie J, West-Mays JA. Adenoviral gene transfer of bioactive TGFbeta1 to the rodent eye as a novel model for anterior subcapsular cataract. Mol Vis 2007;13:457-69. [PubMed: 17417606]

Robinson ML. An essential role for FGF receptor signaling in lens development. Semin Cell Dev Biol 2006;17:726-40. [PubMed: 17116415]

Rossi M, Morita H, Sormunen R, Airenne S, Kreivi M, Wang L, Fukai N, Olsen B, Tryggvason K, Soininen R. Heparan sulfate chains of perlecan are indispensable in the lens capsule but not in the kidney. EMBO J 2003;22:236-245. [PubMed: 12514129]

Ruoslahti E, Engvall E, Hayman EG. Fibronectin: current concepts of its structure and functions. Coll Relat Res 1981;1:95-128. [PubMed: 7049547]

Ruoslahti E, Pierschbacher M, Engvall E, Oldberg A, Hayman EG. Molecular and biological interactions of fibronectin. J Invest Dermatol 1982;79(Suppl 1):65s-68s. [PubMed: 7045246]

Sabah J, McConkey E, Welti R, Albin K, Takemoto LJ. Role of albumin as a fatty acid carrier for biosynthesis of lens lipids. Exp Eye Res 2005;80:31-6. [PubMed: 15652523]

Sabah JR, Davidson H, McConkey EN, Takemoto L. In vivo passage of albumin from the aqueous humor into the lens. Mol Vis 2004;10:254-9. [PubMed: 15073582]

Salzmann, M. The Anatomy and Histology of the Human Eyeball in the Normal State. Franz Deuticke, Leipzig and Wien; Germany: 1912.

Sasaki T, Fukai N, Mann K, Gohring W, Olsen BR, Timpl R. Structure, function and tissue forms of the C-terminal globular domain of collagen XVIII containing the angiogenesis inhibitor endostatin. Embo J 1998;17:4249-56. [PubMed: 9687493]

Schachar RA. Zonular function: a new hypothesis with clinical implications. Ann Ophthalmol 1994;26:36-8. [PubMed: 8010701]

Schachar RA. The mechanism of accommodation and presbyopia. Int Ophthalmol Clin 2006;46:39-61. [PubMed: 16929224]

Schachar RA, Koivula A. The stress on the anterior lens surface during human in vivo accommodation. Br J Ophthalmol 2008;92:348-50. [PubMed: 18211940]

Schymeinsky J, Nedbal S, Miosge N, Poschl E, Rao C, Beier DR, Skarnes WC, Timpl R, Bader BL. Gene Structure and Functional Analysis of the Mouse Nidogen-2 Gene: Nidogen-2 Is Not Essential for Basement Membrane Formation in Mice. Mol. Cell. Biol 2002;22:6820-6830. [PubMed: 12215539]

Seland JH. Ultrastructural changes in the normal human lens capsule from birth to old age. Acta Ophthalmol 1974;52:688-706. [PubMed: 4138136] 
Seland JH. Production of human lens capsule illustrated by a case of chronic lenticular chalcosis. Acta Ophthalmol (Copenh) 1976;54:301-10. [PubMed: 181943]

Semina EV, Bosenko DV, Zinkevich NC, Soules KA, Hyde DR, Vihtelic TS, Willer GB, Gregg RG, Link BA. Mutations in laminin alpha 1 result in complex, lens-independent ocular phenotypes in zebrafish. Dev Biol 2006;299:63-77. [PubMed: 16973147]

Simirskii VN, Wang Y, Duncan MK. Conditional deletion of beta1-integrin from the developing lens leads to loss of the lens epithelial phenotype. Dev Biol 2007;306:658-68. [PubMed: 17493607]

Siperstein M, Unger R, Madison L. Studies of muscle capillary basement membranes in normal subjects, diabetic, and prediabetic patients. J Clin Invest 1968;47:1973-1999. [PubMed: 5675423]

Sivak JG. Accommodation in vertebrates: a contemporary survey. Curr Top Eye Res 1980;3:281-330. [PubMed: 7344838]

Smith BS. Histochemical analysis of extracellular matrix material in embryonic trisomy 1 mouse eye. Dev Genet 1989;10:287-91. [PubMed: 2791349]

Sramek SJ, Wallow IH, Bindley C, Sterken G. Fibronectin distribution in the rat eye. An immunohistochemical study. Invest Ophthalmol Vis Sci 1987;28:500-5. [PubMed: 3557863]

Streeten BW. The zonular insertion: a scanning electron microscopic study. Invest Ophthalmol Vis Sci 1977;16:364-75. [PubMed: 844993]

Sundelin K, Sjostrand J. Posterior capsule opacification 5 years after extracapsular cataract extraction. J Cataract Refract Surg 1999;25:246-50. [PubMed: 9951672]

Takei K, Furuya A, Hommura S, Yamaguchi N. Ultrastructural fragility and type IV collagen abnormality of the anterior lens capsules in a patient with Alport syndrome. Jpn J Ophthalmol 2001;45:103-4. [PubMed: 11163053]

Tamiya S, Wormstone IM, Marcantonio JM, Gavrilovic J, Duncan G. Induction of matrix metalloproteinases 2 and 9 following stress to the lens. Exp Eye Res 2000;71:591-7. [PubMed: 11095911]

Thim K, Krag S, Corydon L. Stretching capacity of capsulorhexis and nucleus delivery. J Cataract Refract Surg 1991;17:27-31. [PubMed: 2005555]

Thim K, Krag S, Corydon L. Hydroexpression and viscoexpression of the nucleus through a continuous circular capsulorhexis. J Cataract Refract Surg 1993;19:209-12. [PubMed: 8487162]

Tholozan FM, Gribbon C, Li Z, Goldberg MW, Prescott AR, McKie N, Quinlan RA. FGF-2 release from the lens capsule by MMP-2 maintains lens epithelial cell viability. Mol Biol Cell 2007;18:422231. [PubMed: 17699594]

Thorleifsson G, Magnusson KP, Sulem P, Walters GB, Gudbjartsson DF, Stefansson H, Jonsson T, Jonasdottir A, Stefansdottir G, Masson G, Hardarson GA, Petursson H, Arnarsson A, Motallebipour M, Wallerman O, Wadelius C, Gulcher JR, Thorsteinsdottir U, Kong A, Jonasson F, Stefansson K. Common sequence variants in the LOXL1 gene confer susceptibility to exfoliation glaucoma. Science 2007;317:1397-400. [PubMed: 17690259]

Timpl R, Brown JC. Supramolecular assembly of basement membranes. Bioessays 1996;18:123-32. [PubMed: 8851045]

Tsilibary EC, Charonis AS, Reger LA, Wohlhueter RM, Furcht LT. The effect of nonenzymatic glucosylation on the binding of the main noncollagenous NC1 domain to type IV collagen. J Biol Chem 1988;263:4302-8. [PubMed: 3346249]

Uchimura K, Morimoto-Tomita M, Bistrup A, Li J, Lyon M, Gallagher J, Werb Z, Rosen SD. HSulf-2, an extracellular endoglucosamine-6-sulfatase, selectively mobilizes heparin-bound growth factors and chemokines: effects on VEGF, FGF-1, and SDF-1. BMC Biochem 2006;7:2. [PubMed: 16417632]

Van Agtmael T, Schlotzer-Schrehardt U, McKie L, Brownstein DG, Lee AW, Cross SH, Sado Y, Mullins JJ, Poschl E, Jackson IJ. Dominant mutations of Col4a1 result in basement membrane defects which lead to anterior segment dysgenesis and glomerulopathy. Hum. Mol. Genet 2005;14:3161-3168. [PubMed: 16159887]

van der Woerdt A. Lens-induced uveitis. Vet Ophthalmol 2000;3:227-234. [PubMed: 11397308]

Vlodavsky I, Bar-Shavit R, Ishai-Michaeli R, Bashkin P, Fuks Z. Extracellular sequestration and release of fibroblast growth factor: a regulatory mechanism? Trends Biochem Sci 1991;16:268-71. [PubMed: 1926336] 
Vu TH, Werb Z. Matrix metalloproteinases: effectors of development and normal physiology. Genes Dev 2000;14:2123-33. [PubMed: 10970876]

Walker JL, Zhang L, Zhou J, Woolkalis MJ, Menko AS. Role for alpha 6 integrin during lens development: Evidence for signaling through IGF-1R and ERK. Dev Dyn 2002;223:273-84. [PubMed: 11836791]

Weale RA. The accommodation of lens implants. Ophthalmic Res 2005;37:156-8. [PubMed: 15925909]

Webster EH Jr. Searls RL, Hilfer SR, Zwaan J. Accumulation and distribution of sulfated materials in the maturing mouse lens capsule. Anat Rec 1987;218:329-37. [PubMed: 3631545]

Webster EH Jr. Zwaan J. The appearance of alpha, beta and gamma crystallins in an anophthalmic strain of mice. Differentiation 1984;27:53-8. [PubMed: 6468804]

Wheatley HM, Traboulsi EI, Flowers BE, Maumenee IH, Azar D, Pyeritz RE, Whittum-Hudson JA. Immunohistochemical localization of fibrillin in human ocular tissues. Relevance to the Marfan syndrome. Arch Ophthalmol 1995;113:103-9. [PubMed: 7826283]

Wilson ME Jr. Trivedi RH, Biber JM, Golub R. Anterior capsule rupture and subsequent cataract formation in Alport syndrome. J Aapos 2006;10:182-3. [PubMed: 16678759]

Winkler J, Wirbelauer C, Frank V, Laqua H. Quantitative distribution of glycosaminoglycans in young and senile (cataractous) anterior lens capsules. Exp Eye Res 2001;72:311-8. [PubMed: 11180980]

Wormstone IM, Liu CS, Rakic JM, Marcantonio JM, Vrensen GF, Duncan G. Human lens epithelial cell proliferation in a protein-free medium. Invest Ophthalmol Vis Sci 1997;38:396-404. [PubMed: 9040473]

Wormstone IM, Tamiya S, Anderson I, Duncan G. TGF-beta2-induced matrix modification and cell transdifferentiation in the human lens capsular bag. Invest Ophthalmol Vis Sci 2002;43:2301-8. [PubMed: 12091431]

Yan Q, Blake D, Clark JI, Sage EH. Expression of the matricellular protein SPARC in murine lens: SPARC is necessary for the structural integrity of the capsular basement membrane. J Histochem Cytochem 2003;51:503-11. [PubMed: 12642629]

Yan Q, Clark JI, Sage EH. Expression and characterization of SPARC in human lens and in the aqueous and vitreous humors. Exp Eye Res 2000;71:81-90. [PubMed: 10880278]

Yan Q, Clark JI, Wight TN, Sage EH. Alterations in the lens capsule contribute to cataractogenesis in SPARC-null mice. J Cell Sci 2002;115:2747-56. [PubMed: 12077365]

Yan Q, Perdue N, Blake D, Sage EH. Absence of SPARC in murine lens epithelium leads to increased deposition of laminin-1 in lens capsule. Invest Ophthalmol Vis Sci 2005;46:4652-60. [PubMed: 16303962]

Yan Q, Sage EH. SPARC, a matricellular glycoprotein with important biological functions. J Histochem Cytochem 1999;47:1495-506. [PubMed: 10567433]

Ylikarppa R, Eklund L, Sormunen R, Kontiola AI, Utriainen A, Maatta M, Fukai N, Olsen BR, Pihlajaniemi T. Lack of type XVIII collagen results in anterior ocular defects. Faseb J 2003a; 17:2257-9. [PubMed: 14525950]

Ylikarppa R, Eklund L, Sormunen R, Muona A, Fukai N, Olsen BR, Pihlajaniemi T. Double knockout mice reveal a lack of major functional compensation between collagens XV and XVIII. Matrix Biol 2003b;22:443-8. [PubMed: 14614990]

Young RW, Ocumpaugh DE. Autoradiographic studies on the growth and development of the lens capsule in the rat. Invest Ophthalmol 1966;5:583-9. [PubMed: 5954530]

Yurchenco PD, Ruben GC. Basement membrane structure in situ: evidence for lateral associations in the type IV collagen network. J Cell Biol 1987;105:2559-68. [PubMed: 3693393]

Yurchenco PD, Tsilibary EC, Charonis AS, Furthmayr H. Models for the self-assembly of basement membrane. J Histochem Cytochem 1986;34:93-102. [PubMed: 3510247]

Zenker M, Tralau T, Lennert T, Pitz S, Mark K, Madlon H, Dotsch J, Reis A, Muntefering H, Neumann LM. Congenital nephrosis, mesangial sclerosis, and distinct eye abnormalities with microcoria: an autosomal recessive syndrome. Am J Med Genet A 2004;130:138-45. [PubMed: 15372515]

Zhao H, Yang T, Madakashira BP, Thiels CA, Bechtle CA, Garcia CM, Zhang H, Yu K, Ornitz DM, Beebe DC, Robinson ML. Fibroblast growth factor receptor signaling is essential for lens fiber cell differentiation. Dev Biol 2008;318:276-88. [PubMed: 18455718] 
Ziebarth NM, Borja D, Arrieta E, Aly M, Manns F, Dortonne I, Nankivil D, Jain R, Parel JM. Role of the lens capsule on the mechanical accommodative response in a lens stretcher. Invest Ophthalmol Vis Sci. 2008

Zinkevich NS, Bosenko DV, Link BA, Semina EV. laminin alpha 1 gene is essential for normal lens development in zebrafish. BMC Dev Biol 2006;6:13. [PubMed: 16522196]

Zuk A, Kleinman HK, Hay ED. Culture on basement membrane does not reverse the phenotype of lens derived mesenchyme-like cells. Int J Dev Biol 1989;33:487-90. [PubMed: 2641354] 


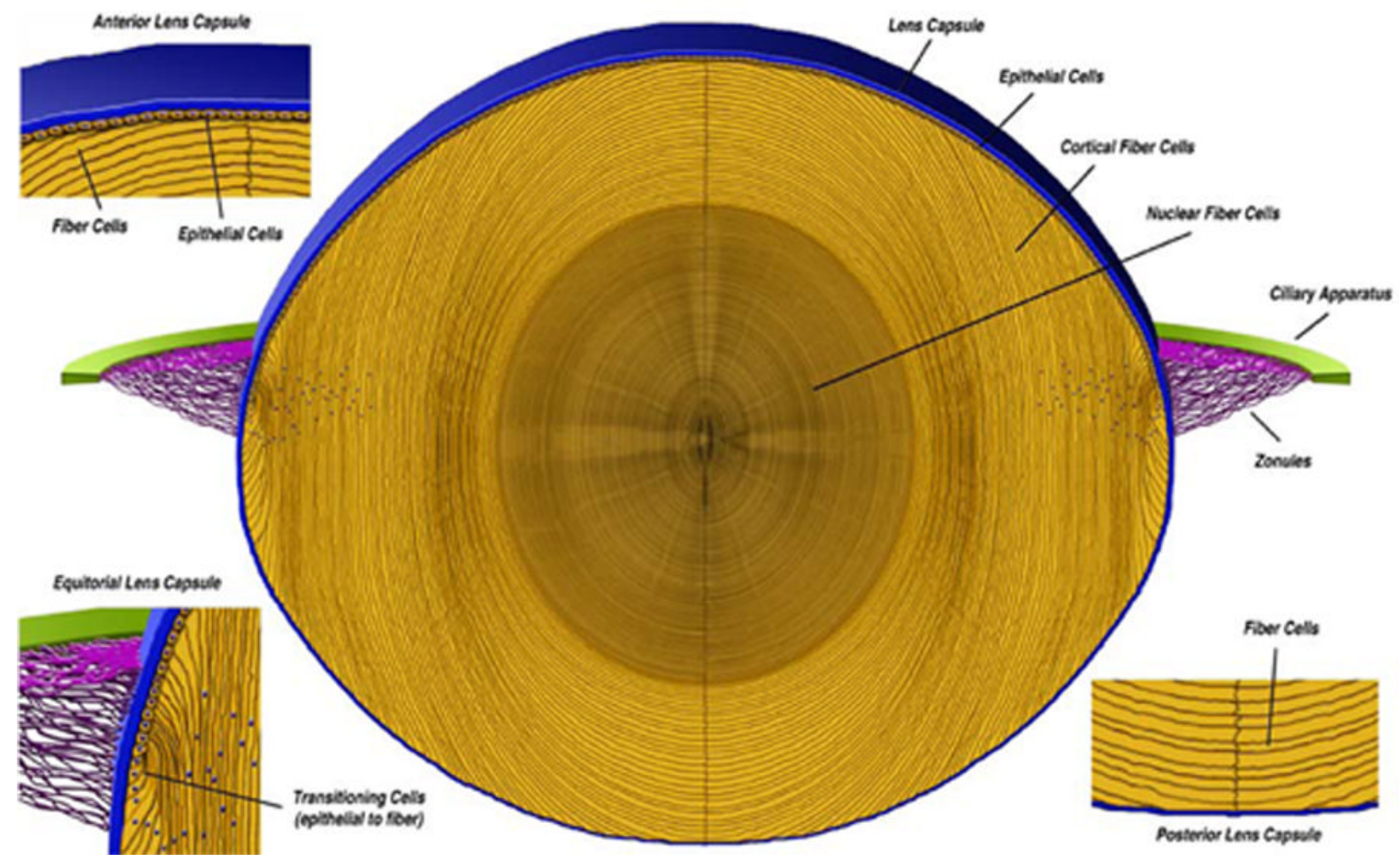

Figure 1.

A cross section of an adult mouse lens showing the lens capsule (blue) surrounding the cellular lens (yellow). The anterior and posterior lens capsules are the basement membranes for the lens epithelial cells and the lens cortical fiber cells, respectively. In the equatorial region the lens capsule serves as the basement membrane for the epithelial cells differentiating into fiber cells and is also the site of zonule (purple) integration. 


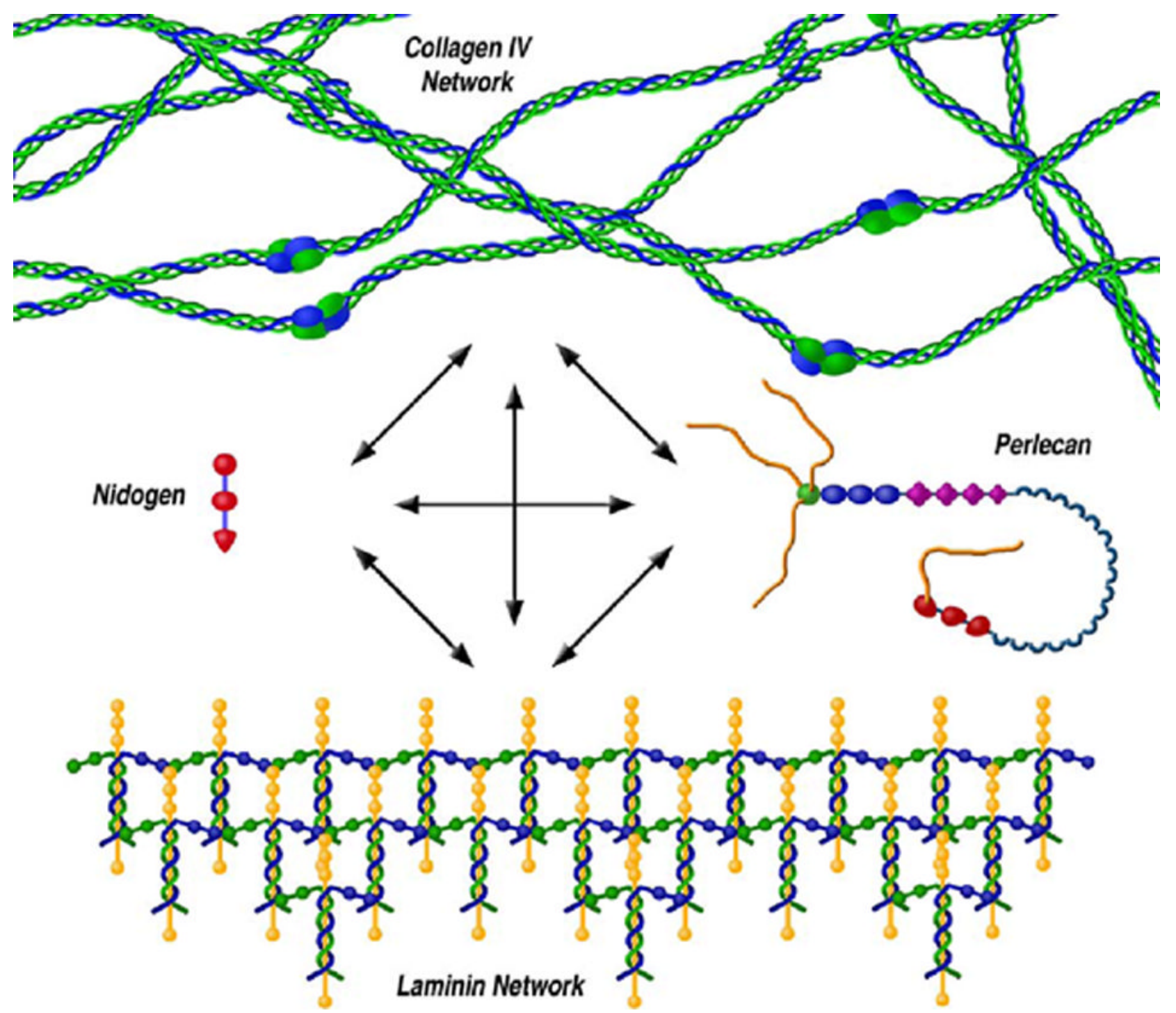

Figure 2.

The lens capsule is a matrix of molecules consisting primarily of interacting collagen IV and laminin networks which are further bound together by nidogen and perlecan. The interactions between all four molecules and water create a viscoelastic membrane capable of withstanding and transmitting the forces of accommodation. Other molecules important for lens biology are also capable of binding to this scaffolding such as collagen XVIII and a variety of growth factors. 


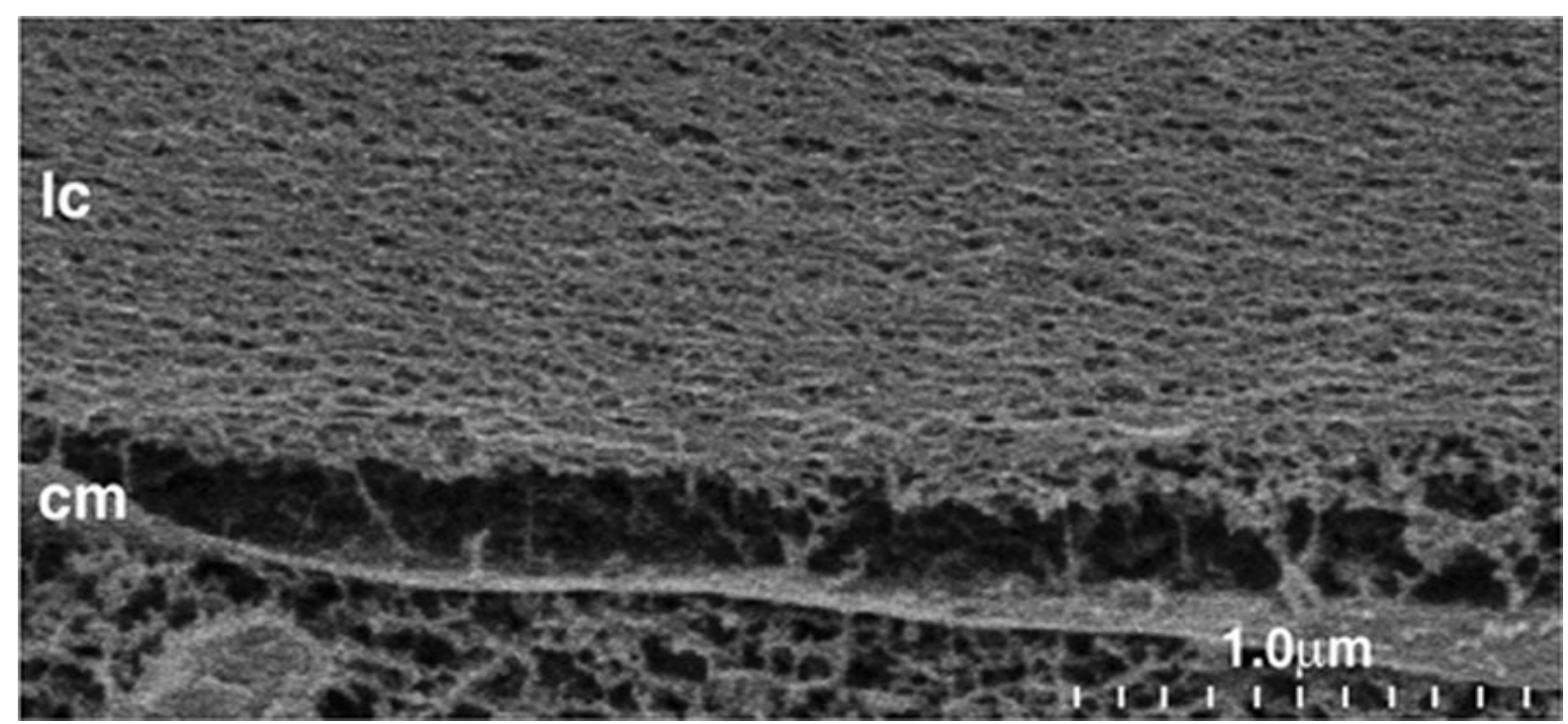

Figure 3.

A cryo-SEM image $(35,000 X)$ showing lens capsule (lc) slightly separated from an epithelial cell membrane $(\mathrm{cm})$. The meshwork structure of the capsule is apparent. 

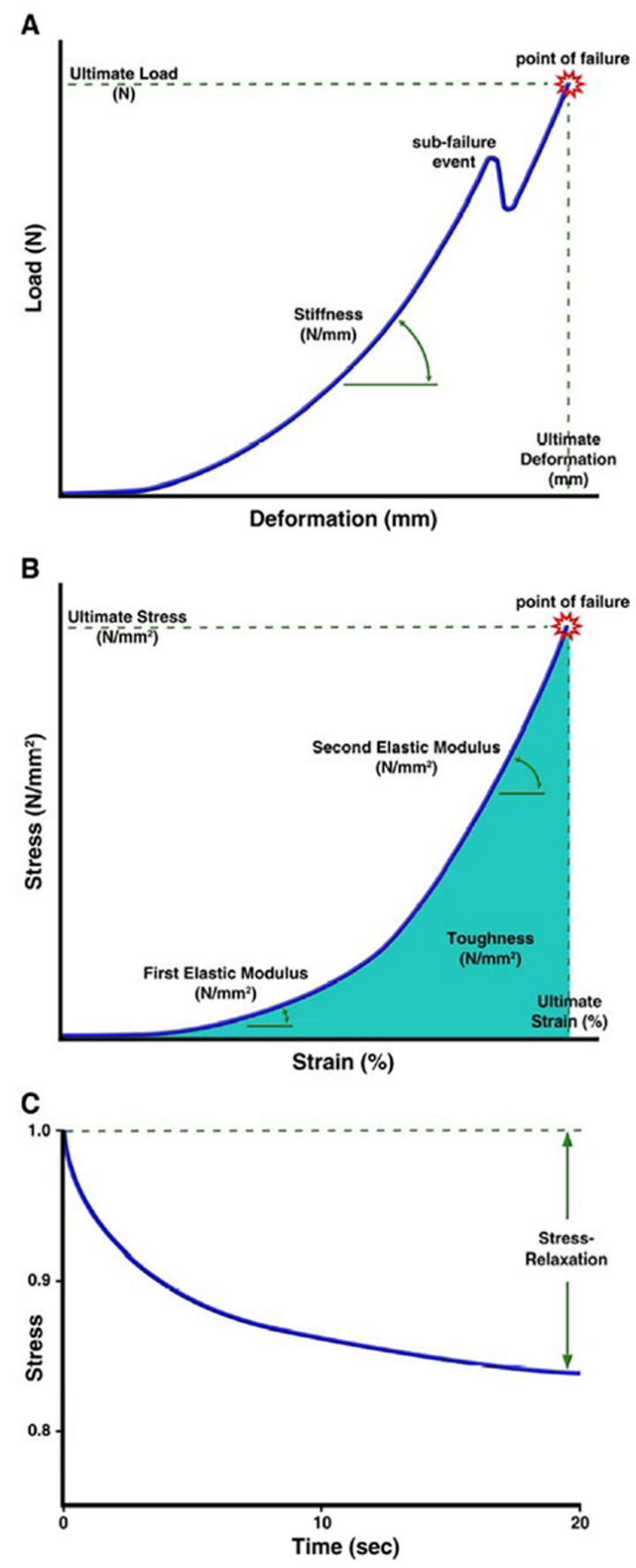

Figure 4.

a) A load-deformation curve represents the capsule's structural parameters as a function of the capsule's geometry when an increasing uniaxial or biaxial load or deformation is applied.

Stiffness is determined from a linear slope fit to this curve while ultimate load and deformation is the point of complete lens capsule failure. Sub-failure events represent the breaking of individual matrix bonds or tissue layers prior to complete failure. b) The load-deformation relationship is normalized into a stress-strain curve to account for differences in the dimensions of the capsule. This relationship represents the intrinsic properties of the lens capsule material. Elastic moduli are determined by fitting linear slopes to regions of the curve. The area under the stress-strain curve represents the toughness of the capsule while the ultimate stress and 
strains are determined at the point of lens capsule failure. c) Stress-relaxation is the responding change in stress over time after a constant strain is applied to a viscoelastic material. After the initial strain is applied (time zero) to the lens capsule, the matrix relaxes over time resulting in a reduction in stress. The stress-relaxation is reported as the percent stress relief after a given time as a result of the constant applied strain. 